\title{
30. DEFORMATION HISTORY OF PERIDOTITES FROM THE MARIANA FOREARC, CONICAL SEAMOUNT, LEG $125^{1}$
}

\author{
Jacques Girardeau ${ }^{2}$ and Yves Lagabrielle ${ }^{3}$
}

\begin{abstract}
Abundant serpentinite seamounts are found along the outer high of the Mariana forearc at the top of the inner slope of the trench. One of them, Conical Seamount, was drilled at Sites 778, 779, and 780 during Leg 125.

The rocks recovered at Holes $779 \mathrm{~A}$ and $780 \mathrm{C}$, respectively, on the flanks and at the summit of the seamount, include moderately serpentinized depleted harzburgites and some dunites. These rocks exhibit evidence of resorption of the orthopyroxene, when present, and the local presence of very calcic-rich diopside in veins oblique to the main high-temperature foliation of the rock.

The peridotites, initially well-foliated with locally poikiloblastic textures, show overprints of a two-stage deformation history: (1) a high-temperature $\left(>1000^{\circ} \mathrm{C}\right)$, low-stress $(0.02 \mathrm{GPa})$, homogeneous deformation that has led to the present porphyroclastic textures displayed by the rocks and (2) heterogeneous ductile shearing at a much higher stress $(0.05 \mathrm{GPa})$. This heterogeneous shearing probably describes a single tectonic event because it began at high temperatures, producing dynamic recrystallization of olivine in the shear zone, and ended at low temperatures in the stability field of chlorite and serpentine. In a few samples, olivine shows evidence of quasi-hydrostatic recrystallization at a very high temperature. Here, we propose that this recrystallization was related to fluid/magma percolation, a process that can also account for the resorption of the orthopyroxene and for the late crystallization of diopside veins in the rock.

The impregnation by fluid or magma, development of the main high-temperature, low-stress deformation, and subsequent migration recrystallization of olivine probably occurred in a mantle fragment involved in the arc formation. In addition, this mantle has preserved structures that may have formed earlier in the oceanic lithosphere upon which the arc formed.

Heterogeneous ductile shear zones in the peridotites may have developed during uplift. The "cold" deformation may have taken place during diapiric rise of hot mantle that underwent subsequent serpentinization or gliding along normal faults associated with the extension of the eastern margin of the forearc.
\end{abstract}

\section{INTRODUCTION}

Subduction-related magmatic processes have been studied intensively, mainly by means of geochemical investigations of arc lavas. Until now, however, the deepest parts of island-arc systems have remained largely unknown because of sampling difficulties. Consequently, few data are available on peridotites from subduction-related active margins, in contrast to abundant data on peridotites from true oceanic domains, ridges, transform-fault segments of ridges, and incipient oceans. However, significant petrological, geochemical, and textural changes are predicted to occur in the supra-subduction mantle to explain the unique characteristics of arc lavas.

Almost no data are available on the structure of peridotites from supra-subduction-zone settings, except those published by Shcherbakov and Savel'Yeva (1984) on samples from the Mariana trench. Other data concern the petrology of some peridotites dredged from the outer wall of the Puerto Rico trench (Bowin et al., 1966) and mostly from the inner slope of the Mariana (Bloomer, 1983; Bloomer and Hawkins, 1983; Ishii, 1985; T. Ishii, pers. comm., 1990) and Tonga (Bloomer and Fisher, 1987; Saraskin et al., 1983) trenches. Most of these peridotites have experienced a high degree of melting and depletion, as evidenced by the very low modal content of clinopyroxene in these rocks and by the high $\mathrm{Mg} / \mathrm{Mg}+\mathrm{Fe}(\mathrm{Mg} \#)$ and $\mathrm{Cr} / \mathrm{Cr}+\mathrm{Al}(\mathrm{Cr} \#)$ contents of spinels (Mysen and Kushiro, 1977; Jakes and Green, 1980), which have compositions close to spinels from island-arc lavas (Dick and Bullen, 1984) and from peridotites of ophiolites that are supposed to have formed in subduction-zone environments (see discussion in Pearce et al., 1984, and in Bonatti and Michael, 1989). Traces of impregnation by basaltic liquids also

\footnotetext{
'Fryer, P., Pearce, J. A., Stokking, L. B., et al., 1992. Proc. ODP, Sci. Results, 125: College Station, TX (Ocean Drilling Program).

IPGP-UP7, 2 Place Jussieu, F-75252 Paris Cédex 05, France. (Present address: Université de Nantes, 2 Rue de la Houssinière, F-44072 Nantes Cédex 03, France.)

${ }^{3}$ GDRGEDO, 6 Avenue Le-Gorgeu, F-29287 Brest Cédex, France.
}

have been reported in some ultramafic rocks from the Mariana trench that are more lherzolitic in composition (Bloomer and Hawkins, 1983). The peridotites have undergone intense serpentinization mainly from seawater circulation, but also from water resulting from the dehydration of the subducting slab (Sakai et al., 1990). Most of these ultramafic rocks are recovered with gabbros and basalts: they should be part of an oceanic lithosphere that formed in the island arc (Dietrich et al., 1978; Bloomer and Hawkins, 1983; Ishii, 1985; Johnson et al., 1989; Johnson and Fryer, 1991).

During Leg 125, peridotites from a seamount located between the outer-arc high of the Mariana forearc and trench were cored at Sites 778, 779 , and 780 to constrain their origin and mechanism(s) of uplift (Fryer, Pearce, Stokking, et al., 1990, Fryer et al., 1990; Shipboard Scientific Party, 1990a, 1990b). Because of their location at about $100 \mathrm{~km}$ to the east of the present-day active arc, these rocks might represent part of the basement of the island arc or part of a "pristine" mantle from trapped Pacific Ocean lithosphere. We present a structural study of these peridotites to define their tectonic history and to constrain their origin. The peridotite clasts in sedimentary rocks have been reworked; therefore, special attention has been devoted to the textures to constrain the magmatic and deformational evolution of the rocks during their ascent.

\section{REGIONAL BACKGROUND AND PREVIOUS DATA}

The Mariana Arc constitutes the southern branch of the Izu-BoninMariana arc system, marking the active boundary between the Pacific and the Philippine Sea plates (Fig. 1). This arc represents the eastern border of a complex area comprising several imbricated arcs and basins that began to form during the early-middle Eocene, along with westward subduction of the Pacific Plate. This system, more than $1000 \mathrm{~km}$ wide, includes, from east to west, the trench-related subduction zone; the forearc area; the active island arc; a back-arc basin (the Mariana Trough); the West Mariana Ridge, a now inactive marginal basin (the Parece Vela Basin) and a starved ridge, the Palau Kyushu Ridge. 


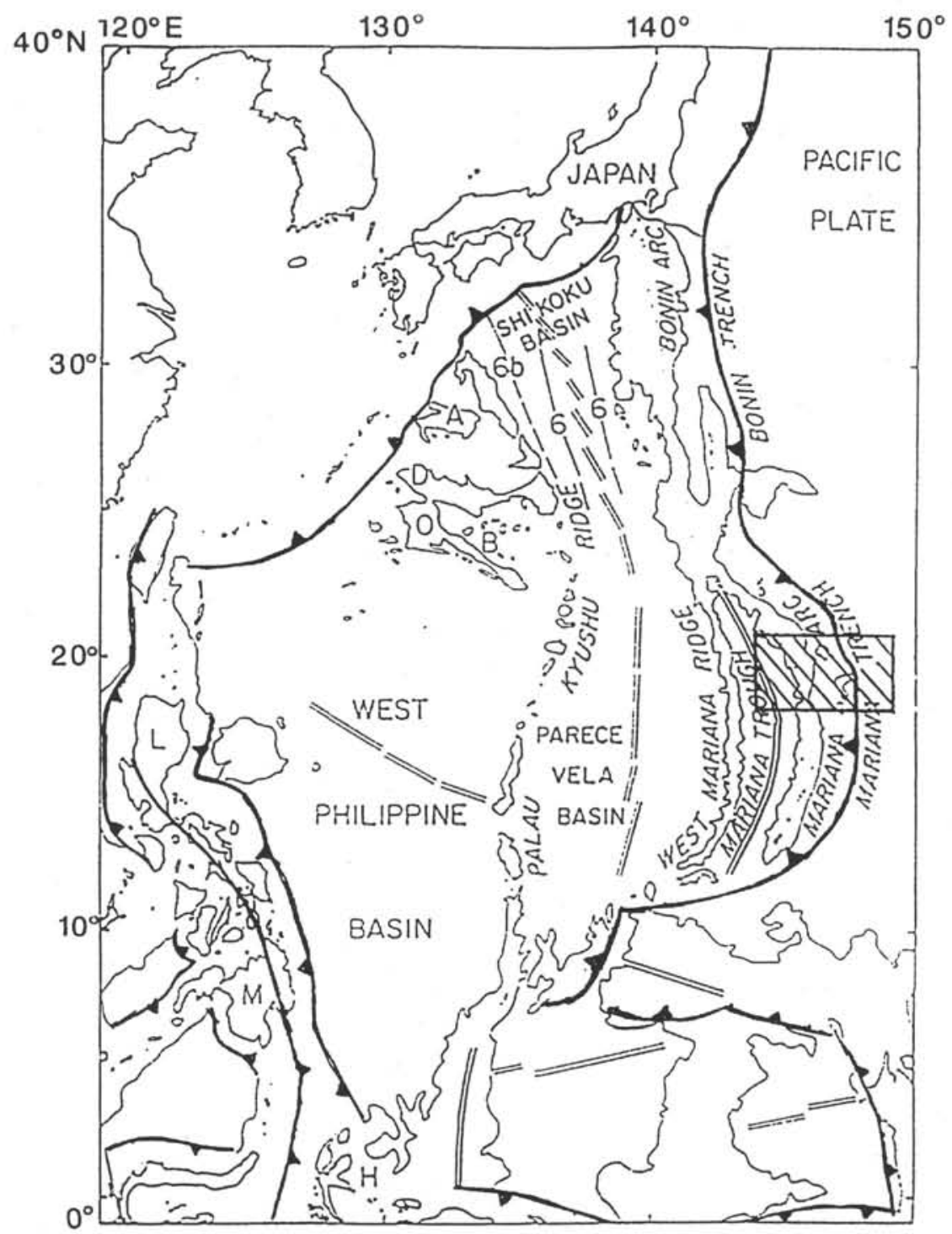

Figure 1. Map of active plate boundaries (bold lines with teeth) between Japan and the Philippine Islands. The hatched rectangle indicates the study area and is shown in Figure 2 (from Fryer, Pearce, Stokking, et al., 1990).

The area between the active Mariana volcanic arc and the trench is about $150 \mathrm{~km}$ wide. This area comprises a deep $(3000 \mathrm{~m})$ basin limited to the east by a high referred to as "the outer arc high" (Fig. 2A). This "outer arc high," which bounds the trench to the west, is characterized by the presence of several serpentinite seamounts (Fryer et al., 1985, 1987). During Leg 125, one of these, the Conical Seamount (Fig. 2B), was cored at its top (Site 780) and flanks (Sites 778 and 779). This seamount has a circular shape, is $20 \mathrm{~km}$ in diameter, and rises $1500 \mathrm{~m}$ above the seafloor. Geophysical and submersible data indicate that this seamount was covered by flows made of serpentine muds (Hussong and Fryer, 1985; Fryer et al., 1987).

Twenty-four of the peridotites studied come from Hole 779A (Fig. 3). This hole, $317.2 \mathrm{~m}$ deep ( $22.9 \%$ recovery), was divided into three lithostratigraphic subunits. Unit I is made up of Holocene to Pleistocene undeformed and unconsolidated clay- to sandsized serpentine sediments (10.6 m thick), Unit II (205.6 m thick) contains clasts of various origins (basalts, gabbros, serpentinites) in a (lower Pleistocene to upper Miocene?) clayey serpentine matrix, with true sedimentary structures in its lower part. Unit III
(14.2 $\mathrm{m}$ thick) is made up of serpentine microbreccias having tectonic structures that could have possibly resulted from gravity sliding on the slope (Shipboard Scientific Party, 1990a). All of the samples studied come from Unit II. However, all are rock fragments without any structural continuity.

Five peridotite samples come from Hole $780 \mathrm{C}$ where a $163.5-\mathrm{m}-$ deep section was cored, with $8.8 \%$ recovery. Two lithological units were recovered: Unit I ( $14 \mathrm{~m}$ thick) is essentially made up of silt- to sand-sized sedimentary serpentine of Holocene to middle Pleistocene age and Unit II (163.5 m thick) consists of serpentinized peridotite blocks in a sandy or clayey serpentine matrix (Shipboard Scientific Party, 1990b). The peridotites are fragments of rocks, centimeter- to decimeter-sized, floating in the sedimentary matrix.

The petrography of the peridotite fragments and the structure of their surrounding matrix were studied directly aboard the ship. The sedimentary matrix clearly displays evidence of shearing and folding at all scales. These structures might represent either primary tectonic gravity deformation structures related to gravity sliding of the unconsolidated material along the slope of the seamount, or recent drilling 

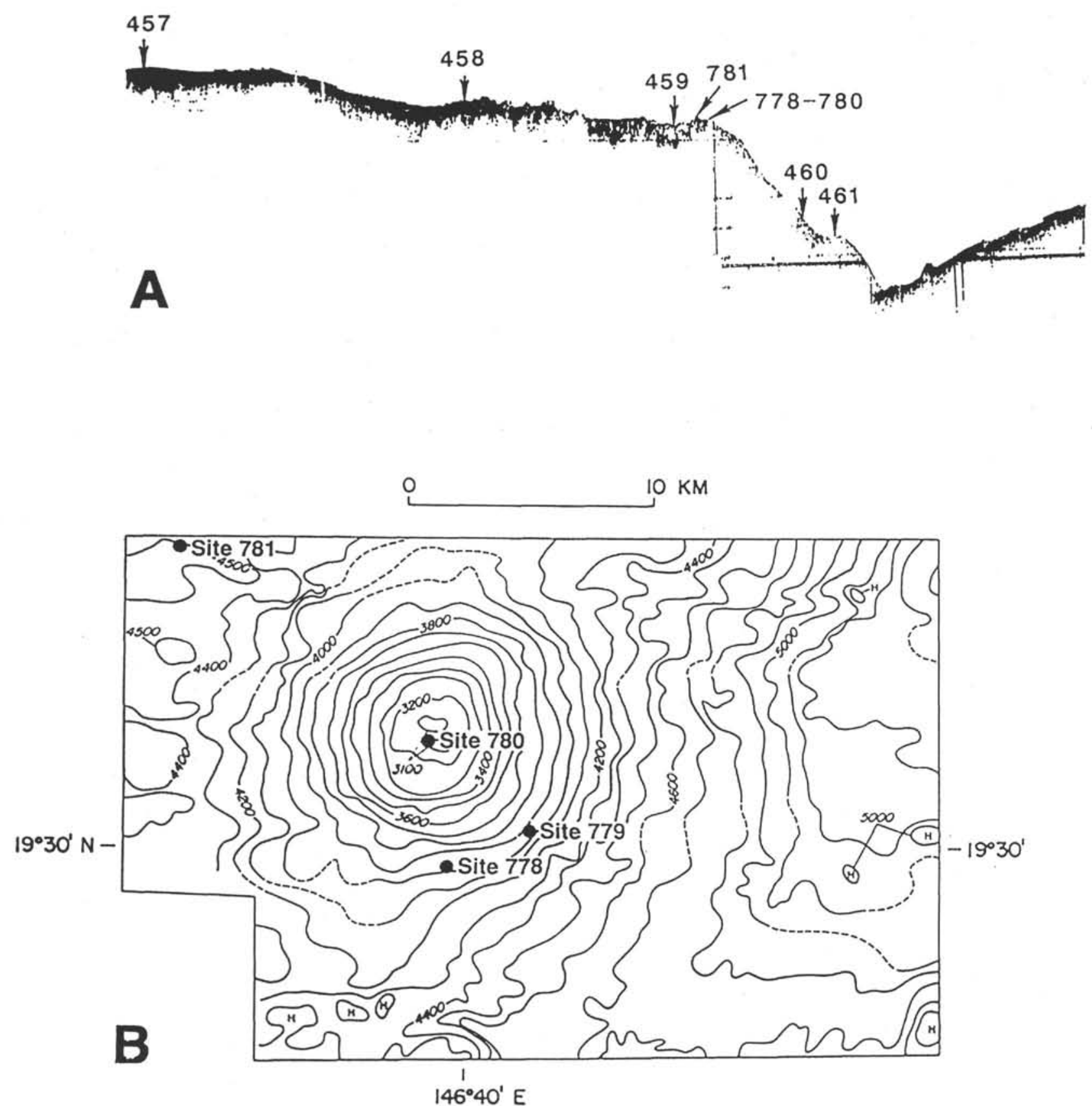

Figure 2. East-west seismic section through the Mariana forearc (A) and bathymetric map of Conical Seamount (B) where Holes 779A and 780C were cored (from Fryer, Pearce, Stokking, et al., 1990).

disturbances. The occurrence of obvious flow structures (observed during SeaMark and diving surveys of the seamount [Hussong and Fryer, 1981; Fryer et al., 1985]) favors a gravity sliding origin for some of the observed structures. Geochemical and mineralogical analyses of serpentine sediments from Hole $778 \mathrm{~A}$ reveal that significant sedimentary reworking and remobilization occurred on the flanks of the seamount in conjunction with gravitational sliding of the serpentine material (Lagabrielle et al., this volume). A subhorizontal schistosity, accompanied locally by slickensides and folding, was observed in some serpentinites.

The consolidated peridotites comprise strongly serpentinized, depleted harzburgites that contain some ( $1 \%-3 \%$ modal) clinopyroxene and minor dunites. Identification of the rocks was made on the basis of petrographical observations and have been confirmed by majorelement chemistry. In some samples, a tectonic fabric (resulting from high-temperature deformation) is present. In addition, some peridotite samples show traces of locally intense brecciation and late-stage veining. The veins show no preferred orientation and record a polystage filling history (Shipboard Scientific Party, 1990a, 1990b).

\section{NEW DATA}

The petrological and structural data presented here result from analysis of 29 samples ( 24 from Hole $779 \mathrm{~A}$ and five from Hole $780 \mathrm{C}$ ) and are based on examination of 93 thin sections. To define and measure the foliation and lineation, which were not directly identified 


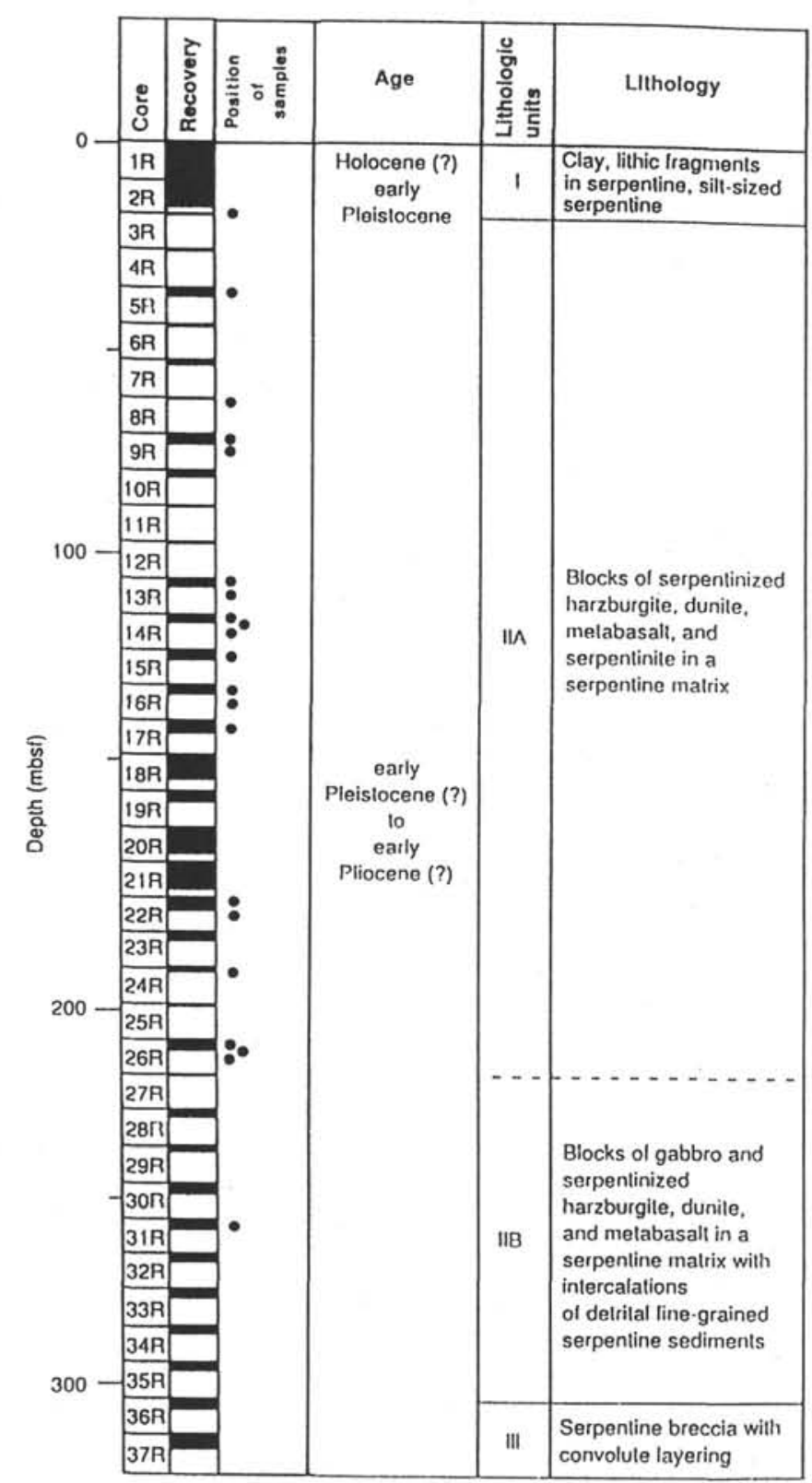

Figure 3. Lithologic summary of Site 779 and location of samples (black indicates recovered rocks).

on the peridotites because of serpentinization, all samples were cut in several planes, including $\mathrm{XZ}$ and $\mathrm{YZ}$ planes for strain-stress analysis. To estimate the thermal evolution of the peridotites, phase composition analyses were conducted using a CAMEBAX electron microprobe (Camparis Université Paris VI). All petrological data are listed in Tables 1 and 2 and all structural data in Tables 3 and 4 . In the text, for convenience, we refer to samples using a simplified identification with numbers ranging from 1 to 29 (column 4 in Tables 1-4). Corresponding Ocean Drilling Program (ODP) numbers are reported in columns 1 through 3 in the tables.

\section{Petrological Data (Tables 1 and 2)}

As mentioned above, many peridotites are strongly altered, with the degree of serpentinization ranging from $100 \%$ in a few samples to $10 \%$ in the better preserved rocks, and having a mean value of about $50 \%$. Nonetheless, most samples contain abundant fresh relics of primary phases: olivine, enstatite, diopside, and spinel. Except for two dunite samples, all peridotites are harzburgites having an average modal composition of $70 \%$ to $85 \%$ olivine, $28 \%$ to $13 \%$ enstatite, and $1 \%$ to $2 \%$ spinel. Diopside never exceeds $1 \%$ of the rock.

Olivine generally is present as small crystals, a few millimeters in size, with lobate and curved contours and with abundant traces of dynamic recrystallization (see below). In many samples, however, olivine constitutes large, elongate porphyroclasts up to $1.5 \mathrm{~cm}$ long, which define a pronounced foliation. The olivine composition ranges from Fo\# 90.6 in the diopside-bearing harzburgites to Fo\# 91.6 in the diopside-free rocks. $\mathrm{NiO}$ content is always high ( $\sim 0.35 \mathrm{wt} \%)$, as is characteristic of residual rocks.

Orthopyroxene grains are small $(<5 \mathrm{~mm})$ throughout the samples. It is present either as isolated crystals scattered in the olivine matrix or as discontinuous aggregates elongated parallel to the spinel foliation. Orthopyroxene characteristically exhibits abundant clinopyroxene exsolution lamellae. The fact that many single crystals are elongated subperpendicular to their exsolution lamellae strongly suggests that they result from dismembering by a pull-apart process of former larger crystals or of a orthopyroxenitic banding. This points to an originally coarser grain size for the initial rock, which is also suggested by the size of some olivine porphyroclast relics. A very important feature of orthopyroxene is that it mostly displays traces of resorption. Most of the crystals are irregularly shaped, and some of them are clearly replaced by secondary olivine (Fig. 4A). Such texture results from the incongruent melting of the orthopyroxene, possibly caused by a reaction with a water-bearing undersaturated fluid that would have percolated into the peridotite (Dick, 1977; Berger and Vannier, 1984), a phenomenon possible in a subduction zone setting. The orthopyroxene is a Mg-rich enstatite having low $\mathrm{Al}_{2} \mathrm{O}_{3}$ content that ranges from 0.7 (wt\%) in the diopside-free harzburgites to $2.8 \mathrm{wt} \%$ in the diopside-bearing ones.

Spinel is abundant in many samples as both isolated crystals scattered in the olivine matrix and in close association with orthopyroxene. In the former case, it generally has an elongate shape with regular contours or is subhedral, as in the dunites. When associated with the orthopyroxene, the shape is amoeboid. Spinels are chromium-rich with their $\mathrm{Cr} \#$ ratio varying from 44.0 in the diopside-bearing harzburgites to $63.6-78.5$ in the diopside-free ones and to 82.0 in the dunites, a feature already pointed out by Ishii et al. (1990). The high chromium content for spinel suggests a high degree of melting for the peridotite (Mysen and Kushiro, 1977; Jakes and Green, 1980). On the other hand, spinel grains always show significant zonation of their $\mathrm{Cr} \#$ and $\mathrm{Mg} \#$ contents from core to periphery ( $2 \%)$. This zonation may have been produced during the uplift of the rocks (e.g., at low rates to allow for aluminum and iron diffusion [Kornprobst and Tabit, 1989] or during late hydrothermal alteration [Kimball, 1990]).

The modal content of clinopyroxene is ubiquitously low, except in one sample (21) in which it attains $1.5 \%$. Clinopyroxene forms either millimeter-sized crystals associated with orthopyroxenes (Fig. 4B), displaying locally single twins, or more generally discontinuous and irregular veins cross-cutting the foliation (Fig. 4C). In the latter case, it commonly surrounds primary spinels. It is also locally associated with minor, small $(0.01 \mathrm{~mm})$ secondary spinels that have a low chromium content ( $\mathrm{Cr} \# 31.3)$. The clinopyroxene veinlets may represent tails of magma that had cut through the peridotite after a main high-temperature deformation. No significant differences exist in the composition of these two types of clinopyroxenes. Both are characterized by high calcium $(\mathrm{CaO}, \sim 24 \mathrm{wt} \%)$ and aluminum $\left(\mathrm{Al}_{2} \mathrm{O}_{3}, \sim 2.65 \mathrm{wt} \%\right)$ contents. They are also rich in $\mathrm{Na}_{2} \mathrm{O}(\sim 0.01 \mathrm{wt} \%)$ and poor in $\mathrm{FeO}$ $(\sim 1.71 \mathrm{wt} \%)$ and $\mathrm{Cr}_{2} \mathrm{O}_{3}(0.89 \mathrm{wt} \%)$, compared with clinopyroxenes from typical residual peridotites. Similar small clinopyroxenes that have a high wollastonite component and occur in veins in close association with spinel have also been described in some peridotites from ophiolites (Orberger and Alleweldt, 1991). They are thought to form through recrystallization of primary clinopyroxenes in the presence of water at low temperatures during late 
stages of peridotite serpentinization. The clinopyroxene-spinel assemblage may also represent the final products of decomposition of the orthopyroxenes during incongruent melting. Using the En-Di Mg-transfer thermometer of Bertrand and Mercier (1985), which is almost insensitive to the composition of the orthopyroxene, one can show that clinopyroxenes of both types have recorded temperatures that range from $950^{\circ}$ to $840^{\circ} \mathrm{C}$ (Table 1).

Secondary phases are present in various amounts in the peridotites. Amphibole (tremolite) develops at the expense of the orthopyroxene in shear zones. These phases are present most commonly in pressure shadows of the orthopyroxene crystals (see discussion in "Deformation" section, this chapter). Talc-chlorite lenses are also present oriented parallel to the amphibole-bearing shear zones. Late chlorite, clinochlore, and magnetite are present in many of the samples, with the latter phase occurring generally in serpentine veins. Serpentine minerals include mainly lizardite and chrysotile. Formation of the latter resulted in a mesh texture for the peridotite. Antigorite also has been reported as a component of some late veins that cross-cut the ultramafic rocks (Shipboard Scientific Party, 1990a, 1990b). Further analyses are needed to determine the exact amount of this phase, however, as transmission electron microscope (TEM) studies in similar rocks from the seamount (Sakai et al., 1990) revealed no antigorite.

\section{Structural Data (Tables 3 and 4)}

Because the internal structure of the peridotites was generally difficult to analyze aboard the ship, a foliation marked by the alignment of orthopyroxene and spinel was recognized only in a few samples (Shipboard Scientific Party, 1990a, 1990b). From the study of the three to four thin sections made from each sample, we were able to define a foliation and a lineation marked by alignment of spinel crystals in each sample. The dip of this foliation and the rake of the lineation have been measured and are listed in Tables 3 and 4 . The dip of foliation varies from $13^{\circ}$ to $80^{\circ}$ and the pitch of lineation from $3^{\circ}$ to $56^{\circ}$ (Fig. 5A, 5B). As expected for blocks floating in a sedimentary matrix, the attitudes are not consistent.

\section{Homogeneous High-Temperature Deformation}

All of the samples display a porphyroclastic texture (Mercier and Nicolas, 1975; Harte, 1977). Some of the peridotites studied are coarse-grained with olivine porphyroclasts of about $1 \mathrm{~cm}$ long. In a few samples, remnants of larger olivine crystals up to $1.5 \mathrm{~cm}$ long and more than $1 \mathrm{~cm}$ wide were observed (Fig. 6A). The initial size of the crystals remains difficult to ascertain because of recrystallization and limited size of the thin section. This fact suggests that the porphyroclastic texture may come from initial poikiloblastic textures. Such a coarse texture suggests that the peridotites underwent recrystallization at high temperatures and under low deviatory stress (Mercier, 1985). The remaining peridotites are finer grained, with rare olivine porphyroclasts generally less than $0.5 \mathrm{~cm}$ in size in a subisotropic matrix of olivine 2 to $3 \mathrm{~mm}$ in size. These samples show a strong foliation marked by the alignment of elongate to holly leaf-shaped spinels that lie within large olivine porphyroclasts (Figs. 6C, 6D).

As shown by the petrofabric diagrams (Fig. 7A), olivine in coarsegrained peridotites displays a good preferred orientation with the [010] axes oriented at high angle to the foliation defined by spinel and the [100] axes close to the lineation. An angle of $14^{\circ}$ was measured between the foliation and shear plane. Thus, the deformation of these peridotites occurred in a rotational regime by intracrystalline glide along the (010)[100] system, which is supposed to be activated at high temperatures and relatively low stress (Carter and Avé Lallemant, 1970; Mercier, 1985). Olivine in a fine-grained porphyroclastic peridotite shows similar fabrics, but with more diffuse orientations of the [010] and [001] axes. As revealed by diagrams in Figure 7B, these axes tend to form girdles subperpendicular to the foliation. Such a fabric may result from the activation of both (010)[100] and (001)[100] slip systems, but at a lower temperature. However, only the $(010)[100]$ high-temperature slip system was determined in that sample on the basis of kink-band geometry (see method described in Nicolas and Poirier, 1976). This fact suggests that the fabric probably resulted from the activation of only the (010)[100] high-temperature slip system, but in a stress regime where $\sigma 1 \sim \sigma 2$. These conditions would have been achieved in cores of diapirs or in rocks largely impregnated by intergranular melt.

In most peridotites, olivine porphyroclasts show large (several millimeters), widely spaced kink-bands. The porphyroclasts often display traces of polygonization and have partly recrystallized at their peripheries into neoblasts, 0.02 to $0.05 \mathrm{~mm}$ in size. The neoblasts are often subpolygonal, with straight boundaries, suggesting that most of the recrystallization occurred through progressive disorientation of subgrains, that is, by the subgrain rotation mechanism (Fig. 6B; Nicolas and Poirier, 1976; Avé Lallemant, 1985). The amount of recrystallization ranges from about $10 \%$ in the less recrystallized facies to more than $50 \%$ in a few samples (Tables 3 and 4). Stress estimates from the neoblast grain size (Mercier et al., 1977; Ross et al., 1980) range from 0.015 to $0.035 \mathrm{GPa}$ in these porphyroclastic peridotites (Tables 3 and 4).

In most samples, the olivine porphyroclasts are clearly elongate, defining a foliation visible only in thin section. This olivine foliation characteristically makes an angle with the spinel foliation which varies from $3^{\circ}$ to $45^{\circ}$, with maximum values between $8^{\circ}$ and $23^{\circ}$ (Fig. 5C). The orthopyroxene is not elongated parallel to the foliation except in two samples $(21,28)$, where it is slightly stretched $(4 \times 1)$ parallel to the spinel alignment. In many rocks, however, it has a rectangular shape, with its larger axis subperpendicular to the spinel foliation, a feature probably resulting from the pulling apart of former larger crystals (Figs. 6C, 6D).

All these data suggest a complex high-temperature deformation history for these peridotites. The earliest recognizable deformation produced the boudinage of large orthopyroxene crystals parallel to a stretching direction marked by spinel alignments. This process probably occurred either at high temperature and pressure or at a much shallower depth, but in the presence of water (Avé Lallemant, 1977). In either case, orthopyroxene was more resistant to strain than the surrounding olivine. The growth of olivine crystals took place during or after this deformation, implying a high-temperature, low-stress event, as suggested by the poikiloblastic texture relics observed in a few samples. This recrystallization phase was followed by a high-temperature $\left(>1000^{\circ} \mathrm{C}\right)$, low-stress $(0.015-0.035 \mathrm{GPa})$ shearing event, which led to the porphyroclastic textures now observed in these rocks.

\section{Heterogeneous Deformation}

A few samples display ductile shear zones slightly oblique to the high-temperature foliation. Two types of shear zones have been recognized: (1) high-temperature ductile shear zones leading to recrystallization of olivine and subsequent development of amphibole and chlorite, and (2) lower temperature ductile shear zones without recrystallization of olivine, but with syntectonic crystallization of amphibole, chlorite, and serpentines. Low-temperature brittle deformation postdates these two events.

\section{High- to Intermediate-Temperature Ductile Shear Zones}

Only two samples $(9,14)$ show the development of high- to intermediate-temperature ductile shear zones (Tables 3 and 4). These ductile shear zones, a few millimeters thick, lie oblique to the foliation marked by the spinel. They stand at $24^{\circ}$ to $28^{\circ}$ to the spinel foliation, but are subparallel to the shear plane defined by the olivine kink-band orientation (Fig. 5C). In the shear zone, olivine has strongly recrystallized into fine-grained (less than $0.01 \mathrm{~mm}$ ) neoblasts that are 
Table 1. Petrologic data for Hole 779A peridotite samples.

\begin{tabular}{|c|c|c|c|c|c|c|c|c|c|c|c|c|c|c|c|c|c|c|c|c|c|c|c|}
\hline \multirow{2}{*}{$\begin{array}{c}\text { Core } \\
3 \\
\end{array}$} & \multirow{2}{*}{\begin{tabular}{|c|} 
Section \\
CC \\
\end{tabular}} & \multirow[t]{2}{*}{$\begin{array}{c}\begin{array}{c}\text { Interval } \\
(\mathrm{cm})\end{array} \\
0-3 \\
\end{array}$} & \multirow[t]{2}{*}{$\begin{array}{c}\text { Thin } \\
\text { Section } \\
\text { number }\end{array}$} & \multirow[t]{2}{*}{\begin{tabular}{|c|}
$\begin{array}{c}\text { Number } \\
\text { of Thin } \\
\text { Sections }\end{array}$ \\
4 \\
\end{tabular}} & \multirow[t]{2}{*}{$\begin{array}{c}\begin{array}{c}\text { Serp. } \\
\%\end{array} \\
50\end{array}$} & \multirow[t]{2}{*}{$\begin{array}{l}\text { Rock } \\
\text { name }\end{array}$} & \multicolumn{2}{|c|}{$\underset{\text { I Paragenesis }}{\text { II }}$} & \multicolumn{3}{|c|}{$\begin{array}{l}\text { Nature of Opx } \\
\text { Isol. } \quad \text { Agg. Res. }\end{array}$} & \multicolumn{2}{|c|}{$\begin{array}{l}\text { Nature of Cpx } \\
\text { En rel. Vein }\end{array}$} & \multicolumn{3}{|c|}{\begin{tabular}{l}
\multicolumn{2}{c}{ Nature of Sp } \\
isol. $\quad$ H.L. En rel.
\end{tabular}} & \multirow[t]{2}{*}{$\begin{array}{l}\mathrm{Mg} \text { " } \\
\text { Ol. \% }\end{array}$} & \multirow[t]{2}{*}{$\begin{array}{l}\mathrm{Cr} \# \\
\mathrm{Sp} . \%\end{array}$} & \multirow[t]{2}{*}{$\begin{array}{c}\mathrm{A} 12 \mathrm{O} 3 \\
\mathrm{En} \\
(\mathrm{m} \%) \\
\end{array}$} & \multicolumn{2}{|c|}{$\begin{array}{c}\mathrm{CaO} \\
\text { Diopside (wr\%) } \\
\text { Opx R. Veins }\end{array}$} & \multicolumn{2}{|c|}{$\begin{array}{c}\text { Temperature } \\
\text { En-Di } \\
\text { (C) }\end{array}$} \\
\hline & & & & & & & ol,en,sp & serp, mg & $\mathrm{x}$ & & $x$ & & & $\mathrm{x}$ & & & & & & & & & \\
\hline 5 & \begin{tabular}{|l|}
2 \\
\end{tabular} & \begin{tabular}{|l|}
$46-49$ \\
\end{tabular} & 2 & \begin{tabular}{|l|}
2 \\
\end{tabular} & $>80$ & harz & $\mathrm{ol}, \mathrm{en}, \mathrm{sp}$ & serp, mg & $x$ & & $x$ & & & $x$ & & & & & & & & & \\
\hline 8 & 1 & 52.54 & 3 & 3 & $>50$ & harz & $\mathrm{ol}, \mathrm{en}, \mathrm{sp}, \mathrm{di}$ & serp & & $x$ & & $\mathrm{x}$ & $x$ & & $x$ & $x$ & & & & & & & \\
\hline 9 & 1 & $129-132$ & 4 & 4 & 40 & harz & ol,sp,en,di & serp,mg & & $x$ & & $x$ & $x$ & $x$ & $x$ & $x$ & & & & & & & \\
\hline 9 & 2 & 2-16 & 5 & 1 & $>70$ & harz & ol,en,sp & serp, mg & $x$ & & $x$ & & & $x$ & $x$ & & & & & & & & \\
\hline 12 & 1 & 52.55 & 6 & 2 & 100 & harz & ol,en,sp & serp,mg & $x$ & & $\mathrm{x}$ & & & $\mathrm{x}$ & $\mathrm{x}$ & $x$ & & & & & & & \\
\hline 13 & 2 & 75.78 & 7 & 4 & 55 & harz & ol,en,sp,di & serp. & $\mathrm{x}$ & $x$ & $\bar{x}$ & $x$ & $\mathrm{x}$ & & $\bar{x}$ & $\bar{x}$ & 90.9 & 44.0 & 2.511 & 23.46 & 24.07 & 960 & 840 \\
\hline 13 & 3 & $14-17$ & 8 & 4 & 50 & harz & ol,en,sp & serp,chl,mg & $x$ & & $\mathrm{x}$ & $\bar{x}$ & & $x$ & & & & & & & & & \\
\hline 14 & 1 & $65-67$ & 9 & 2 & 40 & harz & ol,en,sp & \begin{tabular}{|l|} 
am,chl,talc \\
\end{tabular} & $x$ & & & & & $x$ & & & 91.6 & 63.6 & 2.851 & & 24.95 & & $840-890$ \\
\hline 14 & 2 & $56-59$ & 10 & 4 & 50 & harz & ol,en,sp,di & \begin{tabular}{|l|} 
serp, $\mathrm{mg}$ \\
\end{tabular} & $\mathrm{x}$ & & $x$ & $x$ & $x$ & $x$ & $x$ & $x$ & & & & & & & \\
\hline 14 & 3 & $5-8$ & 11 & 4 & 30 & harz & ol,en,sp,di & \begin{tabular}{|l|} 
serp,chl,mg \\
\end{tabular} & $x$ & & $x$ & & $x$ & $x$ & $x$ & $x$ & & & & & & & \\
\hline 15 & 1 & $65-68$ & 12 & 4 & 50 & harz & d,en,sp,di & $\begin{array}{c}\text { serp,chl,mg } \\
\text {,talc }\end{array}$ & $\mathrm{x}$ & & $\bar{x}$ & & $\bar{x}$ & $\mathrm{x}$ & $\bar{x}$ & & 90.6 & 44.2 & 2.366 & & 24.05 & & 950 \\
\hline 15 & 2 & 1.4 & 13 & 4 & 50 & harz & ol,en,sp & serp,mg & $x$ & & $x$ & & & $x$ & $x$ & $x$ & & & & & & & \\
\hline 16 & 1 & 41.44 & 14 & 4 & 10 & harz & $\mathrm{ol}, \mathrm{en}, \mathrm{sp}$ & serp,chl,mg & & $x$ & & $x$ & $x$ & $x$ & $x$ & & 91.4 & 44.3 & 2.133 & 24.06 & 23.06 & 930 & 850 \\
\hline 16 & 2 & 85.88 & 15 & 4 & 60 & harz & ol,en,sp,di & \begin{tabular}{|l|l} 
serp,mg \\
\end{tabular} & $x$ & $x$ & $x$ & $x$ & $x$ & $x$ & $x$ & $x$ & 91.2 & 51.9 & & & & & \\
\hline 16 & 3 & 53.56 & 16 & 4 & 70 & harz & $\mathrm{ol}, \mathrm{en}, \mathrm{sp}, \mathrm{di}$ & serp,mg & $x$ & $x$ & $x$ & $x$ & & $x$ & & & & & & & & & \\
\hline 17 & 1 & $129-132$ & 29 & 1 & 95 & dun & ol,sp & serp,mg & & & & & & $x$ & & & & & & & & & \\
\hline 22 & 1 & 72.75 & 17 & 4 & 60 & harz & ol,en,sp & serp,chl & $x$ & & $x$ & & & $x$ & & & 91.5 & 78.5 & & 0.754 & & & \\
\hline 22 & 2 & $15-18$ & 18 & 4 & 80 & dun & ol,sp,di & $\begin{array}{c}\text { serp,mg,chl } \\
\text {,talc,ant }\end{array}$ & & & & & $x$ & $\bar{x}$ & & & & & & & & & \\
\hline 24 & 1 & 38.40 & 19 & 1 & 100 & harz & sp & serp,mg,chl & $x$ & $\begin{array}{r}\text { serp, } \\
\text { mg }\end{array}$ & & & & $\bar{x}$ & & & & & & & & & \\
\hline 26 & 1 & $83-86$ & 20 & 3 & 95 & dun & sp & serp,mg & $x$ & & & & & $x$ & & & & & & & & & \\
\hline 26 & 2 & 64.67 & 21 & 4 & 40 & harz & ol,en,sp,di & \begin{tabular}{|l|} 
serp,mg \\
\end{tabular} & $x$ & $x$ & $\mathrm{x}$ & $\mathrm{x}$ & $x$ & $x$ & $x$ & $x$ & 91.0 & 47.0 & 2.608 & 23.99 & 24.38 & 840 & $840-890$ \\
\hline 26 & 3 & 47.50 & 22 & 4 & 50 & harz & $\mathrm{ol}, \mathrm{en}, \mathrm{sp}, \mathrm{di}$ & serp,mg,chl & $x$ & $x$ & & $\mathrm{x}$ & $x$ & $x$ & $x$ & $x$ & & & & & & & \\
\hline 31 & 1 & $34-37$ & 23 & 4 & 100 & breccia & & serp,mg,chl & & & & & & & & & & & & & & & \\
\hline
\end{tabular}

Table 2. Petrologic data for Hole $780 \mathrm{C}$ peridotite samples.

\begin{tabular}{|c|c|c|c|c|c|c|c|c|c|c|c|c|c|c|c|c|c|c|c|c|}
\hline \multirow{2}{*}{$\begin{array}{c}\text { Core } \\
3\end{array}$} & \multirow{2}{*}{$\begin{array}{c}\text { Section } \\
\mathrm{CC}\end{array}$} & \multirow{2}{*}{$\begin{array}{c}\begin{array}{c}\text { Imterval } \\
(\mathrm{mm})\end{array} \\
1-4\end{array}$} & \multirow{2}{*}{$\begin{array}{c}\text { Thin } \\
\text { Soction } \\
\text { Number }\end{array}$} & \multirow{2}{*}{$\begin{array}{l}\begin{array}{c}\text { Number } \\
\text { of thin } \\
\text { sections }\end{array} \\
3\end{array}$} & \multirow{2}{*}{$\begin{array}{c}\underset{\%}{\text { Serp. }} \\
45\end{array}$} & \multirow{2}{*}{$\begin{array}{l}\text { Rock } \\
\text { name }\end{array}$} & \multicolumn{2}{|c|}{$\underset{\text { I }}{\text { Paragenesis }}$ II } & \multicolumn{2}{|c|}{$\begin{array}{l}\text { Nature of Opx } \\
\text { Isol. } \quad \text { Agg. Res. }\end{array}$} & \multicolumn{2}{|c|}{$\begin{array}{l}\text { Nature of Cpx } \\
\text { En rel. Vein }\end{array}$} & \multicolumn{3}{|c|}{$\begin{array}{l}\text { Nature of } \mathrm{Sp} \\
\text { isol. } \quad \text { H.S. En rel. }\end{array}$} & \multirow{2}{*}{$\begin{array}{l}\mathrm{Mg}_{\text {\# }} \\
\text { Ol. \% } \\
91.5\end{array}$} & \multirow{2}{*}{$\begin{array}{r}\begin{array}{c}\text { Cr. } \\
\text { Sp. \% }\end{array} \\
82.0\end{array}$} & \multirow[t]{2}{*}{$\begin{array}{l}\mathrm{Al} 2 \mathrm{O} 3 \\
(\mathrm{w} \%)\end{array}$} & $\begin{array}{c}\mathrm{CaO} \\
\text { Diopside (mo\%) } \\
\text { Opx R. Veins }\end{array}$ & $\begin{array}{c}\text { Temperature } \\
\text { En-Di } \\
\text { (C) }\end{array}$ \\
\hline & & & & & & & ol,sp & $\begin{array}{c}\text { serp,mg, } \\
\text { ant }\end{array}$ & & & & & $\mathrm{x}$ & & & & & & & \\
\hline 8 & 1 & $49-51$ & 25 & 3 & 90 & harz & ol,en,sp & $\begin{array}{c}\text { serp,mg,chl } \\
\text {,am }\end{array}$ & $\bar{x}$ & $x$ & & & $\mathrm{x}$ & $\mathrm{x}$ & $\bar{x}$ & & & & & \\
\hline 9 & 1 & $46-50$ & 26 & 3 & 90 & harz & $\mathrm{ol}, \mathrm{en}$, ,sp,di & serp,mg,ant & $x$ & $x$ & $x$ & $x$ & $x$ & $x$ & & & & & & \\
\hline 13 & 1 & $60-64$ & 27 & 1 & 70 & harz & ol,sp,en,di & serp,mg & $x$ & $x$ & $x$ & $x$ & $\frac{x}{x}$ & $\frac{x}{x}$ & $\bar{x}$ & & & & & \\
\hline 16 & 1 & $55-57$ & 28 & 4 & 80 & harz & ol,en,sp,di & serp,mg & $x$ & $x$ & $x$ & $x$ & $x$ & $x$ & $x$ & & & & & \\
\hline
\end{tabular}

(ol: olivine, sp: spinel, en: enstatite, di: diopside, serp: serpentine, chl: chlorite, mg: magnetite, Isol: isolated, Agg: aggregates, Res: resorbed, En rel: ensté related, H.L.: holly leaf) 
Table 3. Structural data for Hole 779A peridotite samples.

\begin{tabular}{|c|c|c|c|c|c|c|c|c|c|c|c|c|c|c|c|c|c|c|c|c|c|c|c|}
\hline \multirow{2}{*}{$\begin{array}{c}\text { Core } \\
3 \\
\end{array}$} & \multirow{2}{*}{\begin{tabular}{|c|} 
Section \\
$\mathrm{CC}$ \\
\end{tabular}} & \multirow{2}{*}{\begin{tabular}{|c|}
$\begin{array}{l}\text { Interval } \\
\text { (cm) }\end{array}$ \\
0.3 \\
\end{tabular}} & \multirow{2}{*}{$\begin{array}{c}\begin{array}{c}\text { Thin } \\
\text { section } \\
\text { number }\end{array} \\
1\end{array}$} & \multirow{2}{*}{$\begin{array}{l}\text { number } \\
\text { of thin } \\
\text { sections } \\
4\end{array}$} & \multirow{2}{*}{$\begin{array}{c}S 1 \\
\text { dip } \\
\text { degrec }\end{array}$} & \multirow{2}{*}{$\begin{array}{c}\text { L1 } \\
\text { pitch } \\
\text { degrec }\end{array}$} & \multicolumn{2}{|c|}{$\begin{array}{l}\text { Foliation marked by } \\
\text { Spinel Ol/ En }\end{array}$} & $\begin{array}{c}\text { Angle } \\
\text { Sisp/S1OI } \\
\text { degroce } \\
\end{array}$ & $\begin{array}{l}\text { Shear } \\
\text { Sense }\end{array}$ & \multicolumn{2}{|c|}{$\begin{array}{l}\text { Textural type } \\
\text { Coarse P. Fine P. }\end{array}$} & \multicolumn{2}{|c|}{$\begin{array}{c}\text { Recrystallization } \\
\text { type } \\
\text { SGR }{ }_{\text {GBM }}\end{array}$} & \multirow{2}{*}{$\begin{array}{c}\begin{array}{c}\% \\
\text { recryst. }\end{array} \\
10 \\
\end{array}$} & \multicolumn{3}{|c|}{$\begin{array}{l}\text { Shear zones } \\
\text { HT IT LT }\end{array}$} & \multirow[t]{2}{*}{$\begin{array}{l}\text { angle } \\
\text { S1ISZ } \\
\text { degree }\end{array}$} & \multirow[t]{2}{*}{$\begin{array}{l}\text { Pull- } \\
\text { Apart } \\
\text { struct. }\end{array}$} & \multirow[t]{2}{*}{$\begin{array}{c}\text { Avenge } \\
\text { Stress } \\
\text { GPa } \\
\end{array}$} & \multirow[t]{2}{*}{$\begin{array}{c}\text { Olivine } \\
\text { glide } \\
\text { system }\end{array}$} & \multirow[t]{2}{*}{$\begin{array}{c}\text { diaclasis } \\
\text { veins }\end{array}$} \\
\hline & & & & & & & $x$ & & & & & $x$ & $\mathrm{x}$ & & & & & & & & & & \\
\hline 5 & \begin{tabular}{|l|}
2 \\
\end{tabular} & $46-49$ & 2 & 2 & & & $x$ & & & & & $x$ & & & & & & & & & & & \\
\hline 8 & 1 & 52.54 & 3 & 3 & & & $x$ & & & & $x$ & & & & 30 & & & & & & & & \\
\hline 9 & 1 & $129-132$ & 4 & 4 & 33 & 73 & $x$ & & & normal & & & $\mathrm{x}$ & & 15 & & & & & & 0.02 & & $x$ \\
\hline 9 & 2 & $2-16$ & 5 & 1 & & & $x$ & & & & & $x$ & & & 50 & & & & & & & & \\
\hline 12 & 1 & 52.55 & 6 & 2 & & & $x$ & of & 24 & & $x$ & & & & 50 & & & & & & 0.02 & & $\mathrm{x}$ \\
\hline 13 & 2 & $75-78$ & 7 & 4 & 13 & 22 & & & & & & & $x$ & & & & & & & & & $(010)(100]$ & $x$ \\
\hline 13 & 3 & $14-17$ & 8 & 4 & $\pi$ & 03 & & of & 45 & dextral & 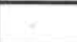 & $x$ & $x$ & & 40 & & $\mathrm{x}$ & $x$ & 30 & & 0.055 & $\begin{array}{l}(010)(100) \\
(001)(100)\end{array}$ & $x$ \\
\hline 14 & 1 & $65-67$ & 9 & 2 & 86 & 83 & $x$ & ol & 16 & inverse & & $x$ & $x$ & tablet & 30 & $x$ & $x$ & & 28 & & 0.040 & $(010)(100]$ & $x$ \\
\hline 14 & 2 & $56-59$ & 10 & 4 & 56 & 06 & $x$ & & & sinistral & & $x$ & & & 20 & & & & & $x$ & 0.015 & & $x$ \\
\hline 14 & 3 & 58 & 11 & 4 & $\pi$ & 05 & $x$ & ol & 10 & sinistral & & $x$ & $\bar{x}$ & & 15 & & & & & & & $(010)(100]$ & $x$ \\
\hline 15 & 1 & $65-68$ & 12 & 4 & 47 & 01 & $x$ & o & 23 & sinistral & & $x$ & $x$ & & 10 & & & & & & 0.020 & $(010)(100]$ & $x$ \\
\hline 15 & 2 & 1.4 & 13 & 4 & & & $x$ & of & 04 & 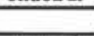 & & $x$ & & & 10 & & & & & & 0.015 & 年 & $x$ \\
\hline 16 & 1 & 41.44 & 14 & 4 & 40 & 56 & $x$ & of & 07 & normal & & $x$ & $x$ & $\begin{array}{c}\text { bulge } \\
\text { n. }\end{array}$ & 30 & $x$ & & & 24 & & 0.060 & $\begin{array}{l}(010)(100) \\
(001)(100)\end{array}$ & $x$ \\
\hline 16 & 2 & $85-88$ & 15 & 4 & 41 & 07 & $x$ & ol & 32 & & & $x$ & & & 10 & & & & & $x$ & & & $x$ \\
\hline 16 & 3 & $53-56$ & 16 & 4 & 45 & 11 & & ol & & & $x$ & & $x$ & & 60 & & & & & & & & $x$ \\
\hline 17 & 1 & $129 \cdot 132$ & 29 & 1 & & & $x$ & & & & & $x$ & & & 10 & & & & & & 0.035 & $(010)(100]$ & $x$ \\
\hline 22 & 1 & 72.75 & 17 & 4 & 07 & 05 & & ol & & sinistral & & $x$ & $\mathrm{x}$ & $x$ & 15 & & & & & & & & $x$ \\
\hline 22 & 2 & $15-18$ & 18 & 4 & 80 & 77 & $x$ & & & inverse & & $x$ & $x$ & & & & & & & & & & $x$ \\
\hline 24 & 1 & 38.40 & 19 & 1 & & & $x$ & of & 16 & & & $x$ & & & 10 & & & & & & & & $x$ \\
\hline 26 & 1 & $83-86$ & 20 & 3 & & & $x$ & & & & & & & & & & & & & & & & $x$ \\
\hline 26 & 2 & $64-67$ & 21 & 4 & 58 & 02 & $x$ & $\mathrm{Ol}+\mathrm{en}$ & 08 & & $x$ & & $x$ & & 20 & & & & & & & & $x$ \\
\hline 26 & 3 & 47.50 & 22 & 4 & 37 & 87 & $x$ & & & inverse & $x$ & & $x$ & & 30 & & & $x$ & & & & & $x$ \\
\hline 31 & 1 & $34-37$ & 23 & 4 & 50 & & & & & normal & & & & & & & & $x$ & & & & & $x$ \\
\hline
\end{tabular}

Table 4. Structural data for Hole $780 \mathrm{C}$ peridotite samples.

\begin{tabular}{|c|c|c|c|c|c|c|c|c|c|c|c|c|c|c|c|c|c|c|c|c|c|c|}
\hline Core & Section & $\begin{array}{l}\text { Interval } \\
(\mathrm{em})\end{array}$ & $\begin{array}{c}\text { Thin } \\
\text { section } \\
\text { number }\end{array}$ & $\begin{array}{l}\text { number } \\
\text { of thin } \\
\text { sections }\end{array}$ & $\begin{array}{c}\text { S1 } \\
\text { dip } \\
\text { degrec }\end{array}$ & $\begin{array}{l}\text { L1 } \\
\text { pitch } \\
\text { degroe }\end{array}$ & $\begin{array}{c}\text { Foliation } \\
\text { Spinel }\end{array}$ & $\begin{array}{l}\text { ruked by } \\
\text { Ol/En }\end{array}$ & $\begin{array}{c}\text { Angle } \\
\text { sisp/s1o1 } \\
\text { degree }\end{array}$ & $\begin{array}{l}\text { Shear } \\
\text { Sense }\end{array}$ & $\begin{array}{c}\text { Tex } \\
\text { Coarse }\end{array}$ & $\begin{array}{l}\text { type } \\
\text { Fine } P .\end{array}$ & $\begin{array}{l}\text { Recrys } \\
\text { SGR }\end{array}$ & $\begin{array}{c}\text { tallization } \\
\text { ype } \\
\text { GBMM }\end{array}$ & $\begin{array}{c}\% \\
\text { recryst. }\end{array}$ & $\begin{array}{l}\text { Shear zor } \\
\text { HT IT }\end{array}$ & $\begin{array}{l}\text { nes } \\
\text { LT }\end{array}$ & $\begin{array}{l}\text { angle } \\
\text { S1/SZ }\end{array}$ & $\begin{array}{l}\text { Pull- } \\
\text { Apart }\end{array}$ & $\begin{array}{l}\text { Average } \\
\text { Stress } \\
\text { GPa }\end{array}$ & $\begin{array}{l}\text { Olivine } \\
\text { glide- } \\
\text { system }\end{array}$ & $\begin{array}{l}\text { diaclasis } \\
\text { veins }\end{array}$ \\
\hline 3 & CC & $1-4$ & 24 & 3 & 10 & 66 & & ol & & normal & $x$ & & $\mathrm{x}$ & & 35 & & & & & 0.015 & $(001)(100)$ & \\
\hline 8 & 1 & $49-51$ & 25 & 3 & 15 & 43 & $x$ & & & & & $x$ & $x$ & & & & & & & & & \\
\hline 9 & 1 & $46-50$ & 26 & 3 & 46 & 03 & $x$ & & & & & $x$ & & & & & & & & & & \\
\hline 13 & 1 & $60-64$ & 27 & 1 & & & $x$ & & & & $x$ & & & & & & & & & & & $x$ \\
\hline 16 & 1 & $55-57$ & 28 & 4 & 48 & 74 & $\bar{x}$ & en & 3 & normal & $x$ & & & & 25 & & & & & 0.020 & & $x$ \\
\hline
\end{tabular}

(ol: olivine, sp: spinel, en: enstatite, di: diopside, S1: foliation; P: porphyroclastic, SGR: sub-grain recrystallization, GBM: grain boundary recrystallization, recryst: recrystallization, HT: high temperature, IT: intermediate temperature, LT: low temperature, struct.: structures, bulge n.: bulge nucleation) 


\section{J. GIRARDEAU, Y. LAGABRIELLE}

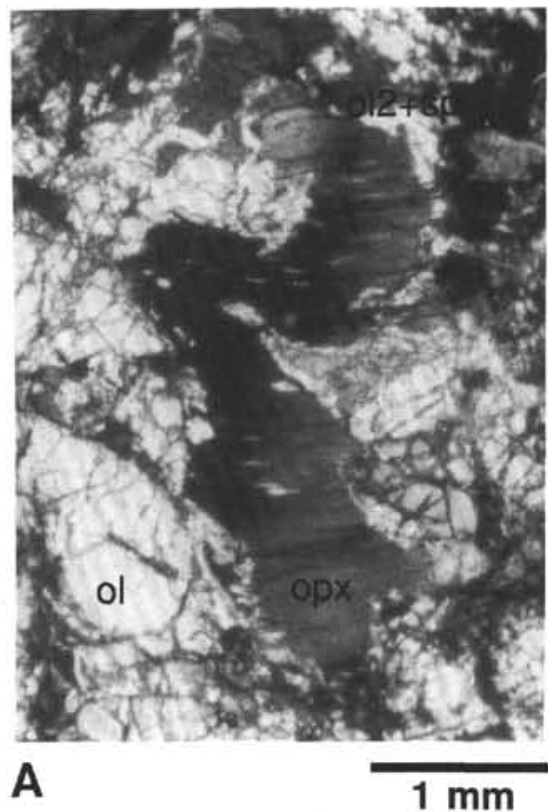

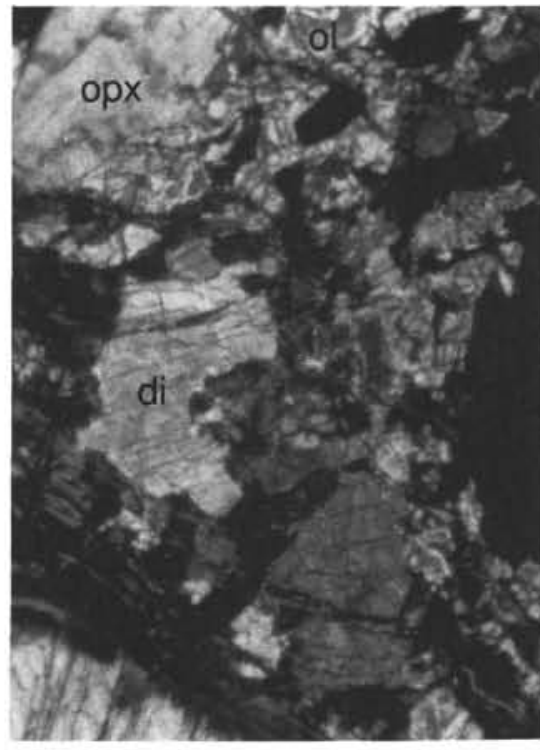

B

$0.5 \mathrm{~mm}$

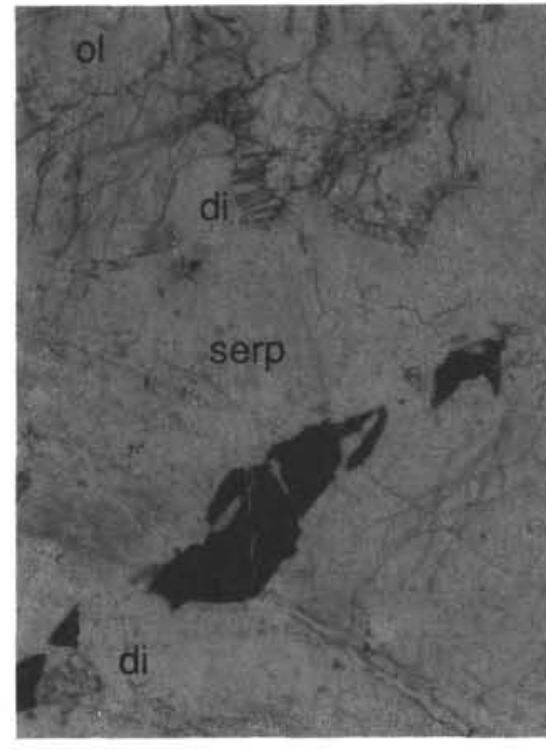

C

$1 \mathrm{~mm}$

Figure 4. Photomicrographs of thin sections showing some peculiar petrological features of the peridotite. A. Resorption of an orthopyroxene crystal in a harzburgite (Sample 125-779A-16R-3, 53-56 cm). B. "Large" clinopyroxene crystals associated with orthopyroxene (Sample 125-779A-26R-2, 64-67 cm). C. "Late" small clinopyroxene crystals occurring in veins cross-cutting the foliation (Sample 125-779A-13R-1, 60-64 cm).
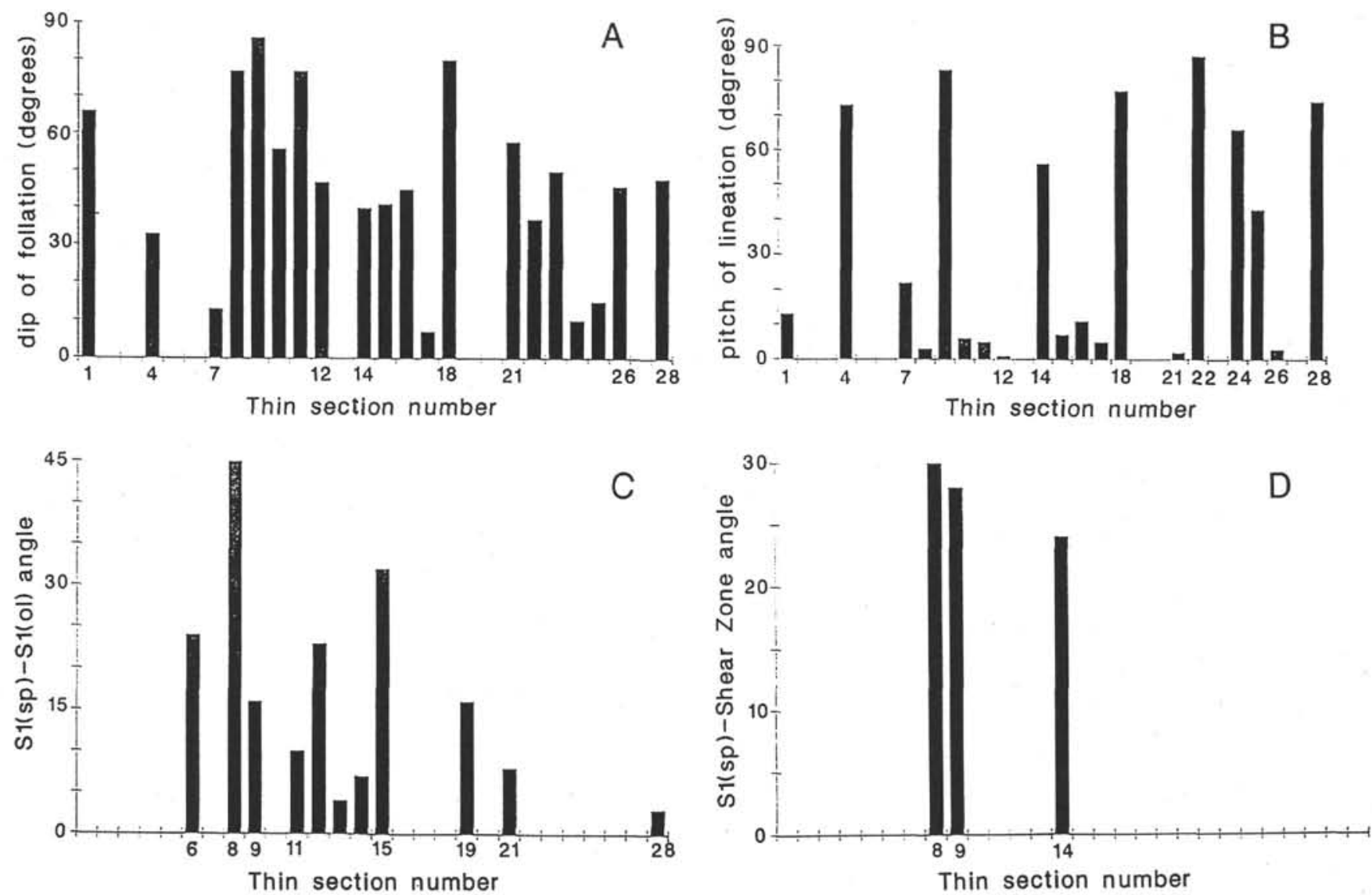

Figure 5. Histograms showing the dip of foliation (A), the rake of lineation (B), and values of the angles between the foliation marked by spinel and olivine (1 to 3 ) (C) and between the spinel foliation and the shear zones (24 to 27) (D). 


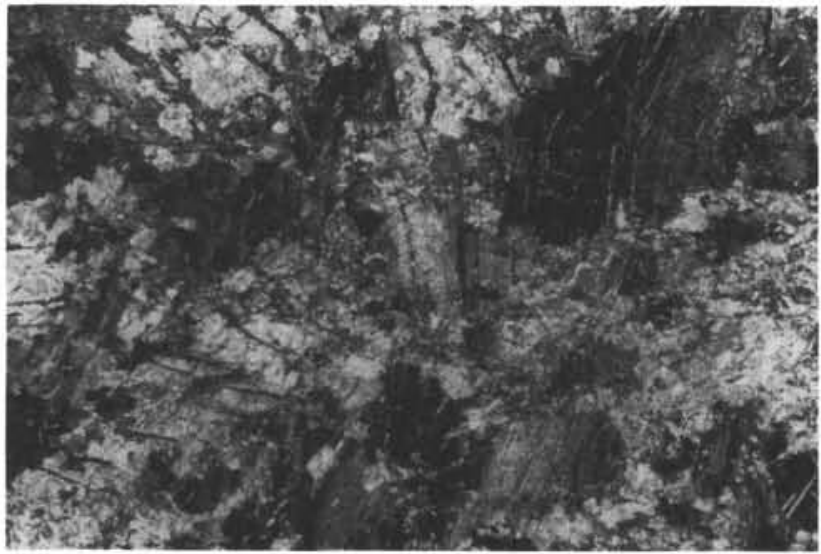

A

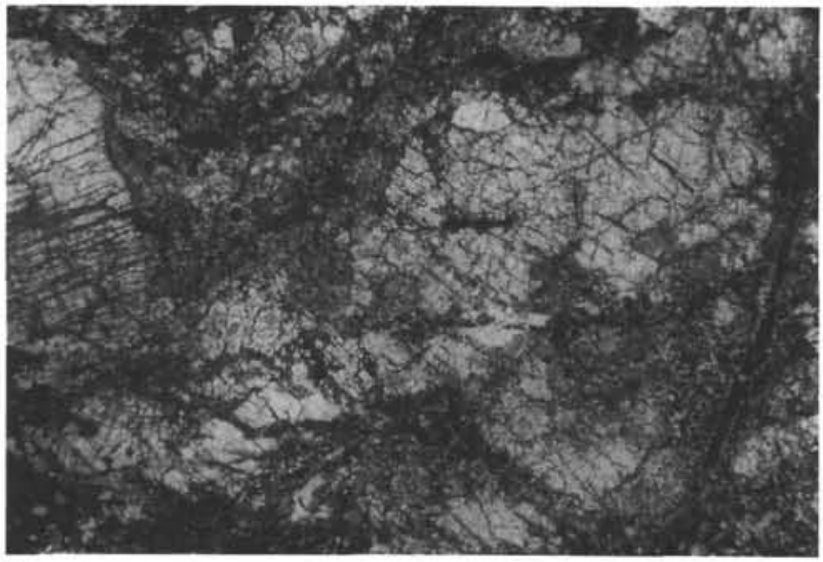

C

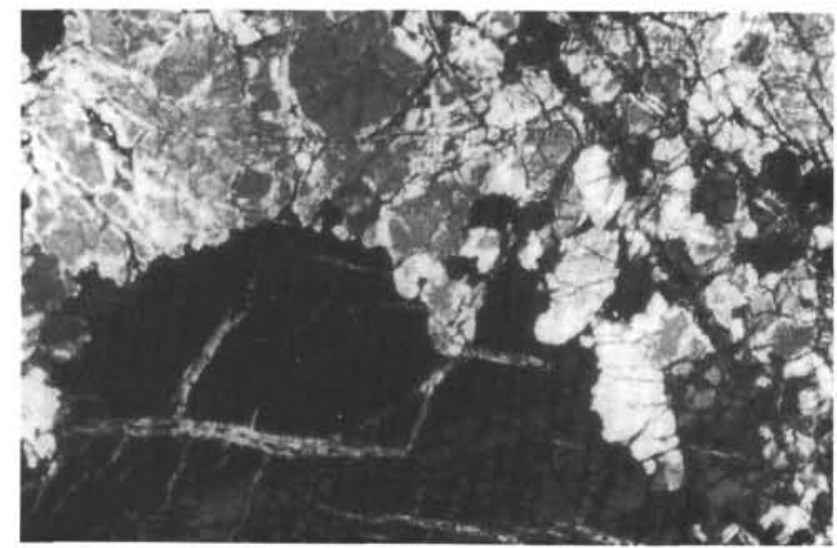

E

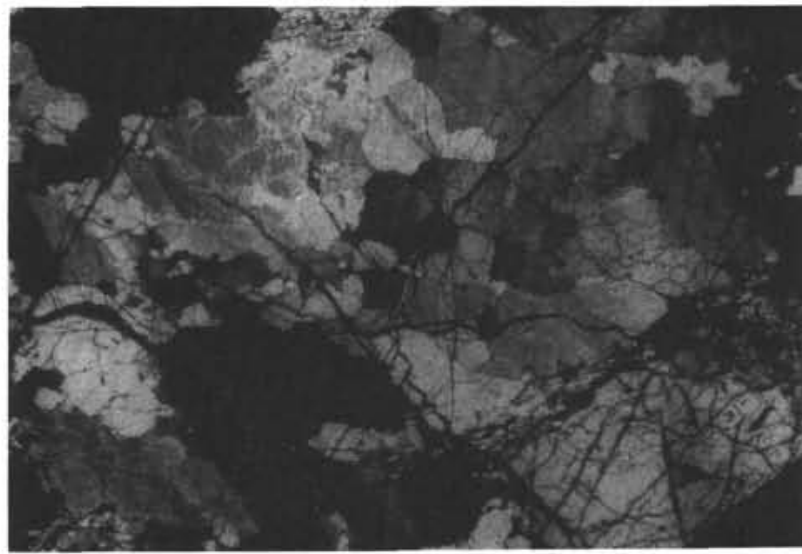

B

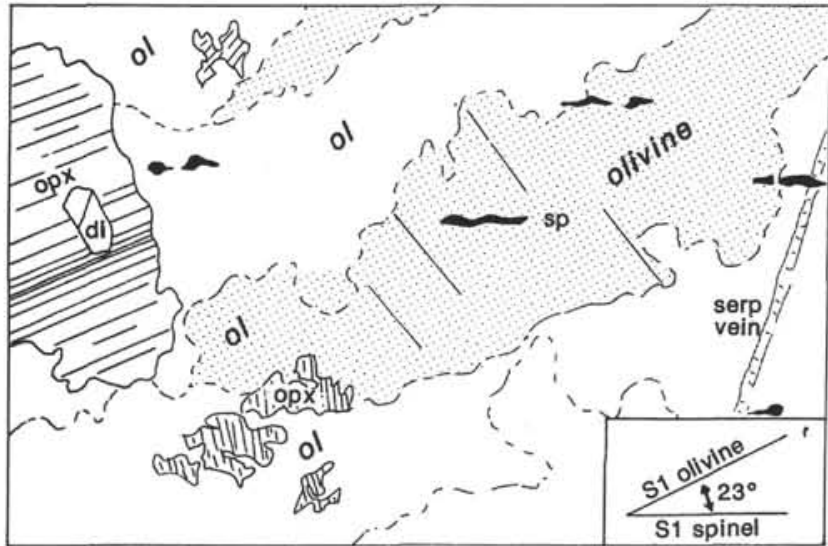

D

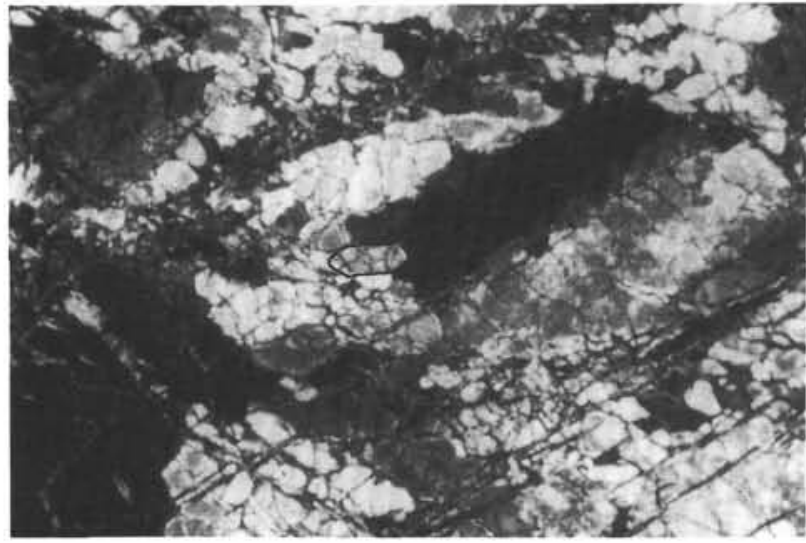

$\mathbf{F}$

Figure 6. Photomicrographs of thin sections showing deformation and recrystallization textures. A. Remnants of a large porphyroclast of olivine in a coarse-grained peridotite (Sample 125-780C-3R-CC, 1-4 cm). B. Subgrain rotation recrystallization in a coarse-grained peridotite (Sample 125-779A-16R-1, 41-46 cm). C-D. Attitude of foliation S1 marked by spinel relative to orthopyroxene and olivine porphyroclast elongation; note the presence of an elongate spinel in a large olivine crystal (Sample 125-779A-15R-2, 1-4 cm). E-F. Evidence for nucleation and grain-boundary migration recrystallization (Sample 125-779A-14R-1, 65-67 cm): bulge nucleation in $(\mathrm{E})$ and tablet-shaped olivine grows at the expense of a highly strained porphyroclast in $(\mathrm{F})$.

slightly elongated parallel to the shear zone and have irregular contours (Fig. 8A). The intensity of recrystallization decreases away from the center of the shear zone. However, it is always present and occurs in pressure shadows of olivine porphyroclast remnants. Stress estimates for the formation of these shear zones range from 0.04 to $0.06 \mathrm{GPa}$ (Tables 3 and 4).
These shear zones also exhibit amphibole growth mainly in the pressure shadows of orthopyroxene crystals and various types of chlorite that generally grow parallel to the shear zone (Fig. 8B). The shear senses were determined using the angle between the foliation and the shear zone, the olivine kink-band geometry, and the olivine and amphibole pressure-shadow patterns. Shears are always in the 

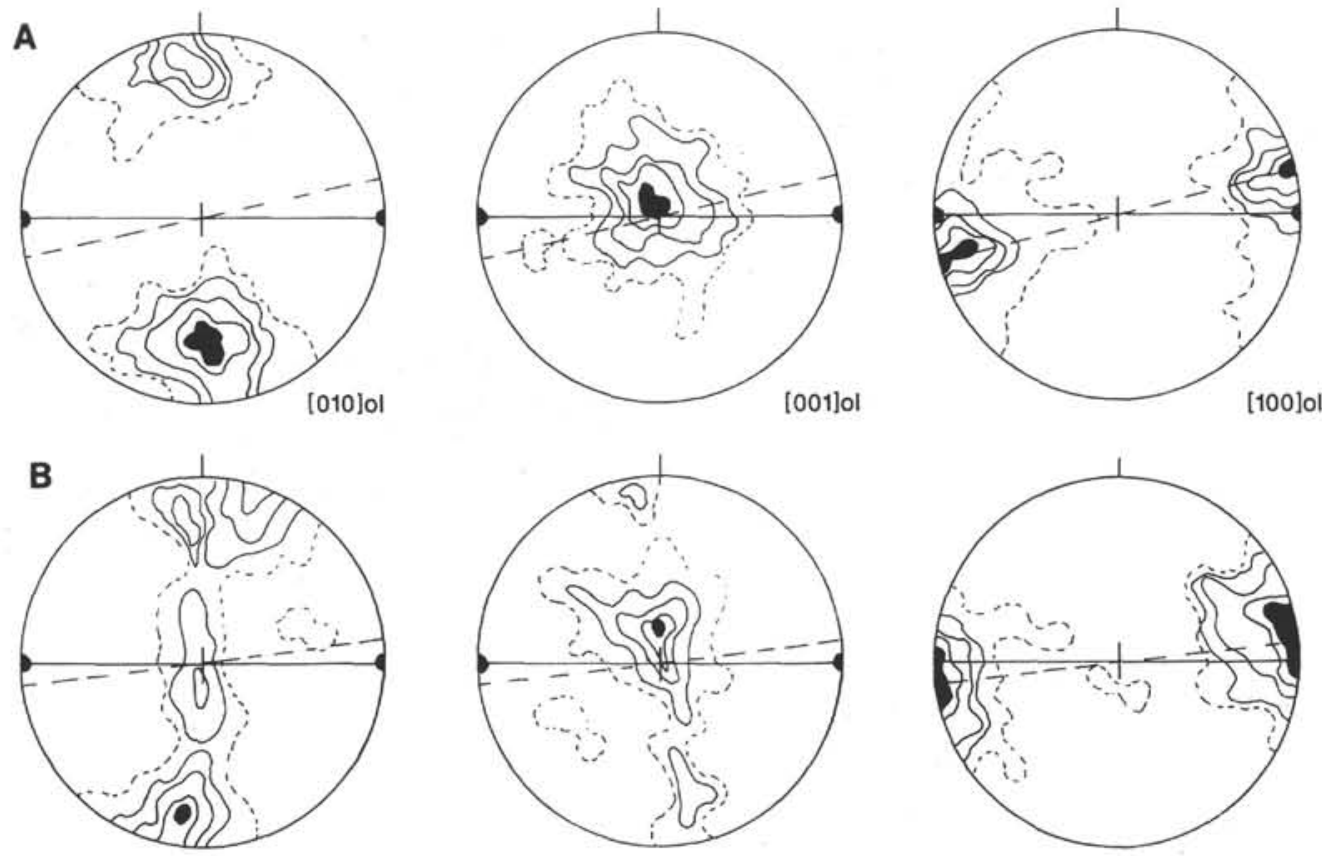

Figure 7. Olivine preferred orientation in coarse-grained (Sample 125-780C-3R-CC, 1-4 cm) (A) and fine-grained (Sample 125-779A-16R-1, 41-44 cm) (B) peridotites (equal-area projection, lower hemisphere). The solid line marks the trace of foliation and the solid dots that of lineation. Dashed lines $=$ shear plane. Contours $=12 \%, 9 \%, 6 \%, 3 \%$, and $2 \%$.

same sense, suggesting that gliding along the shear zone was a continuous phenomenon from high-temperature conditions (recrystallization of olivine) to much lower conditions (syntectonic chlorite).

\section{Intermediate- to Low-Temperature Ductile Shear Zones}

Two samples $(9,15)$ exhibit intermediate- to low-temperature ductile shear zones that developed at high angles $\left(28^{\circ}\right.$ to $\left.30^{\circ}\right)$ to the older foliation marked by the spinel (Fig. 5D; Tables 3 and 4). These shear zones constitute heterogeneous wavy zones along which preexisting crystals have undergone large deformation (e.g., spinel with pull-apart textures [Fig. 8C, 8D]). Synkinematic amphibole, various types of chlorite, serpentines, and magnetites also developed along these shear zones. The amphiboles characteristically crystallized as pressure-shadow tails of orthopyroxene, commonly encountered in the high-temperature shear zones. The sense of shear determined using the crystallization sequence is the same as that determined for the high- to intermediate-temperature shear zones. In one sheared peridotite (23), the primary phases have been completely transformed into a secondary assemblage of serpentine and chlorite in which C/S-type structures are frequent.

The low number of observed shear zones precludes an unambiguous determination of the structural relationships between the high- to intermediate-temperature and the intermediate- to low-temperature ductile deformations. The synkinematic growth of chlorite along the high-temperature shear bands suggests, however, that all shear zones developed during a continuous event at decreasing temperatures.

\section{Brittle Deformation}

As previously mentioned in the "Site 779" and "Site 780" chapters of the Leg 125 Initial Reports (Shipboard Scientific Party, 1990a, 1990b), most of the peridotites exhibit traces of brittle deformation marked either by faults (locally conjugate) devoid of secondary phases or by the development of fractures filled by antigorite, lizardite, and chrysotile (Tables 3 and 4). These faults and veins are at various angles from the main foliation in the rock, with the veins constituting locally an anastomosing net. This brittle deformation phase postdates the main serpentinization of the peridotites.

\section{Evidence for Annealing}

Many of the studied samples show evidence of migration recrystallization. This is well exemplified by the curved grain boundaries of some olivine neoblasts that developed at the periphery or inside strained porphyroclasts and by the interpenetrative growths of olivine crystals bulging out at their grain boundaries (Fig. 5E). The presence of such high-temperature dynamic recrystallization process suggests asthenospheric conditions (Nicolas, 1986).

In one sample (9), a 0.1-mm-long tablet-shaped olivine crystal having straight boundaries developed at the expense of two highly strained olivine porphyroclasts which also exhibited bulge nucleation structures at some of their grain boundaries (Fig. 5F). The development of such olivine tablets is commonly seen in xenoliths from alkali basalts and has been reproduced experimentally (Mercier, 1985). This olivine occurs in strongly strained peridotites which have recrystallized at high temperature under hydrostatic conditions. These tabletshaped olivine crystals should therefore reflect annealing conditions for the peridotite.

The annealing conditions clearly predate the development of the heterogeneous ductile shear zones in the peridotite and likely postdate the main high-temperature plastic deformation of the peridotite responsible for the formation of the porphyroclastic textures. The coexistence of prominent bulge nucleation structures and tablet-shaped crystals in olivine from the same rock suggests that most grain-boundary migration textures occurred under almost hydrostatic conditions. However, it is unlikely that such conditions were achieved in mantle peridotites which were continuously deformed during ascent, but the conditions may have been met in cores of hot diapirs.

One example of annealing with development of tablet-shaped olivine crystals has been recently reported from Oman peridotites (Quatrevaux et al., 1991). That peridotite comes from the center of the Maqsad diapir in a zone where traces of grain-boundary migration 


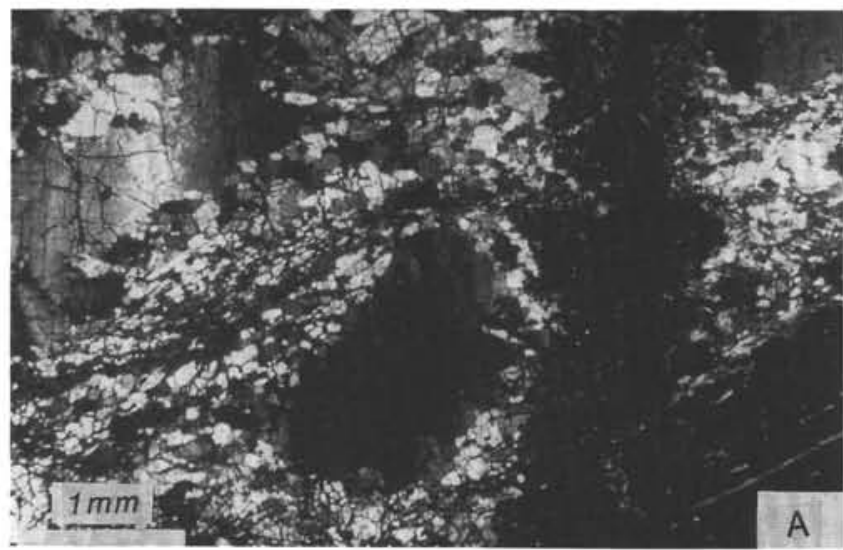

A

$1 \mathrm{~mm}$

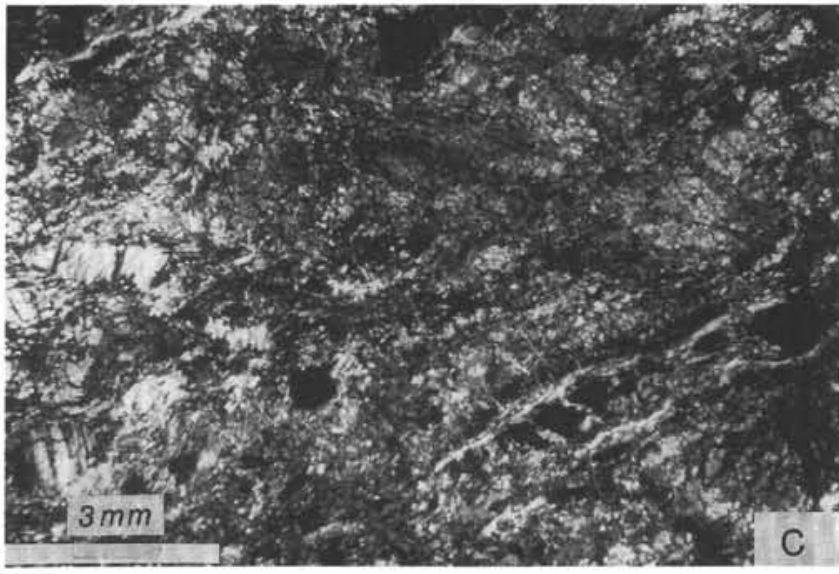

C

$3 \mathrm{~mm}$

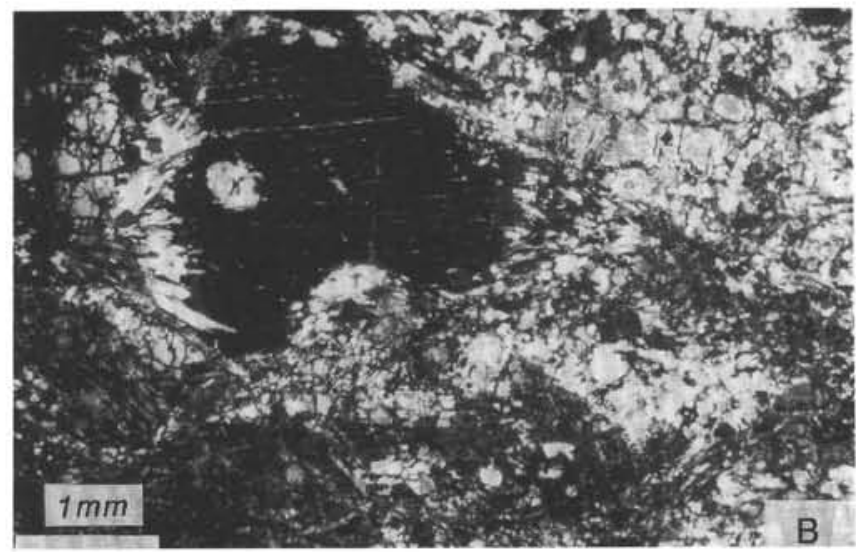

B

$1 \mathrm{~mm}$

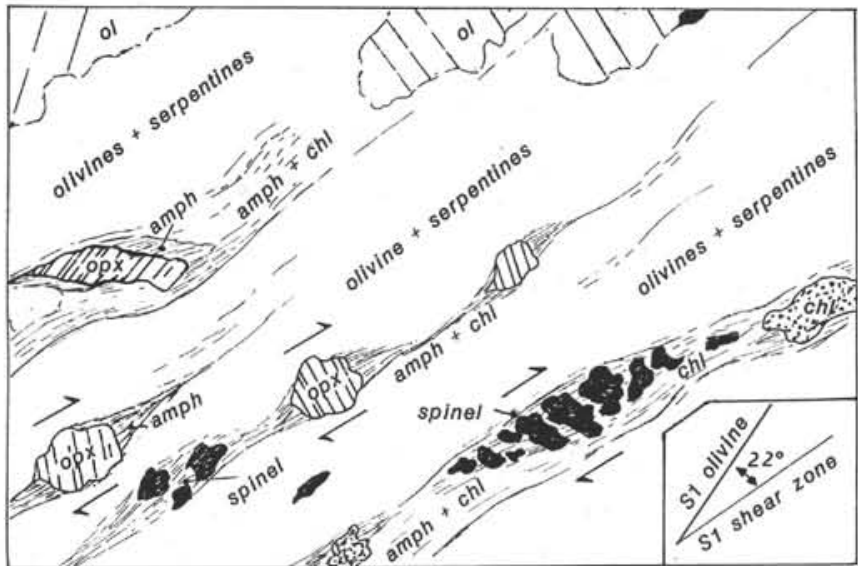

D

Figure 8. Photomicrographs of thin sections showing ductile shear zones. A. Millimeter-sized, high-temperature ductile shear zone marked by dynamic recrystallization of olivine. Note that olivine neoblasts also develop in pressure shadows of olivine porphyroclasts (Sample $125-779 \mathrm{~A}-14 \mathrm{R}-1$, $65-67 \mathrm{~cm}$ ). B. Growth of amphiboles in pressure shadow of a orthopyroxene porphyroclast in an intermediate- to low-temperature, ductile shear zone (Sample 125-779A-13R-3, 14-17 cm). C-D. Attitude of intermediate- to low-temperature ductile shear zones relative to foliation marked by the olivine porphyroclast elongation; see pulled apart structures of spinel (Sample 125-779A-13R-3, 14-17 cm).

recrystallization of olivine are abundant, and where local but significant changes in the modal and chemical compositions of the rock are common. For a number of reasons the annealing process might have been activated by the percolation of hot magma into the peridotite, as might also be the case for the Leg 125 peridotites. This process may also have produced annealing recrystallization in peridotite xenoliths from basalts (Mercier, 1985) and in some metamorphic peridotites recrystallized under hydrous conditions (Nicolas, 1986).

\section{MAIN RESULTS}

Although peridotites from Sites 779 and 780 are blocks set in a sedimentary matrix with no structural continuity, their internal mineralogy and structure may be used to further constrain the evolution of the Mariana forearc basement. Several magmatic and tectonic events may have occurred successively during the ascent of the peridotite. We have summarized these events in the following sections.

\section{High-Temperature Stage (Events 1 to 4)}

This stage, evidenced by a set of various textural arguments, can be divided into four successive events (Fig. 9). Event 1 produced the spinel foliation observed in all rocks, probably during a rotational plastic deformation of the peridotite under asthenospheric conditions. This deformation ended with the coarsening of olivine crystals (event 2 ), giving the rock a coarse-grained, locally poikiloblastic texture, a process that likely occurred at high temperatures in almost hydrostatic conditions. Subsequently, parts of these older textures have been overprinted by a penetrative deformation acquired in a rotational regime at high temperature $\left(>1000^{\circ} \mathrm{C}\right)$ and relatively low $(0.015-$ $0.035 \mathrm{GPa}$ ) stress, which led to the present porphyroclastic texture of the rock (event 3 ). This main plastic deformation was also followed by a high-temperature, almost hydrostatic, event, which permitted some annealing of olivine crystals to occur (event 4).

Event 3 was sealed by the injection of magmas, now represented only by the clinopyroxene + spinel veinlets. Resorption of the orthopyroxene postdates events 1 and 2. This resorption process probably was related to the percolation of hot undersaturated fluids or magmas into the rock which, ultimately led to the crystallization of the clinopyroxene and to secondary spinel after the orthopyroxene. Percolation of these hot fluids (or magmas) might also be responsible for annealing of the olivine (event 4).

\section{Ductile Shearing of Rock (Event 5)}

Development of heterogeneous ductile shear zones followed the homogeneous high-temperature deformation episodes described 

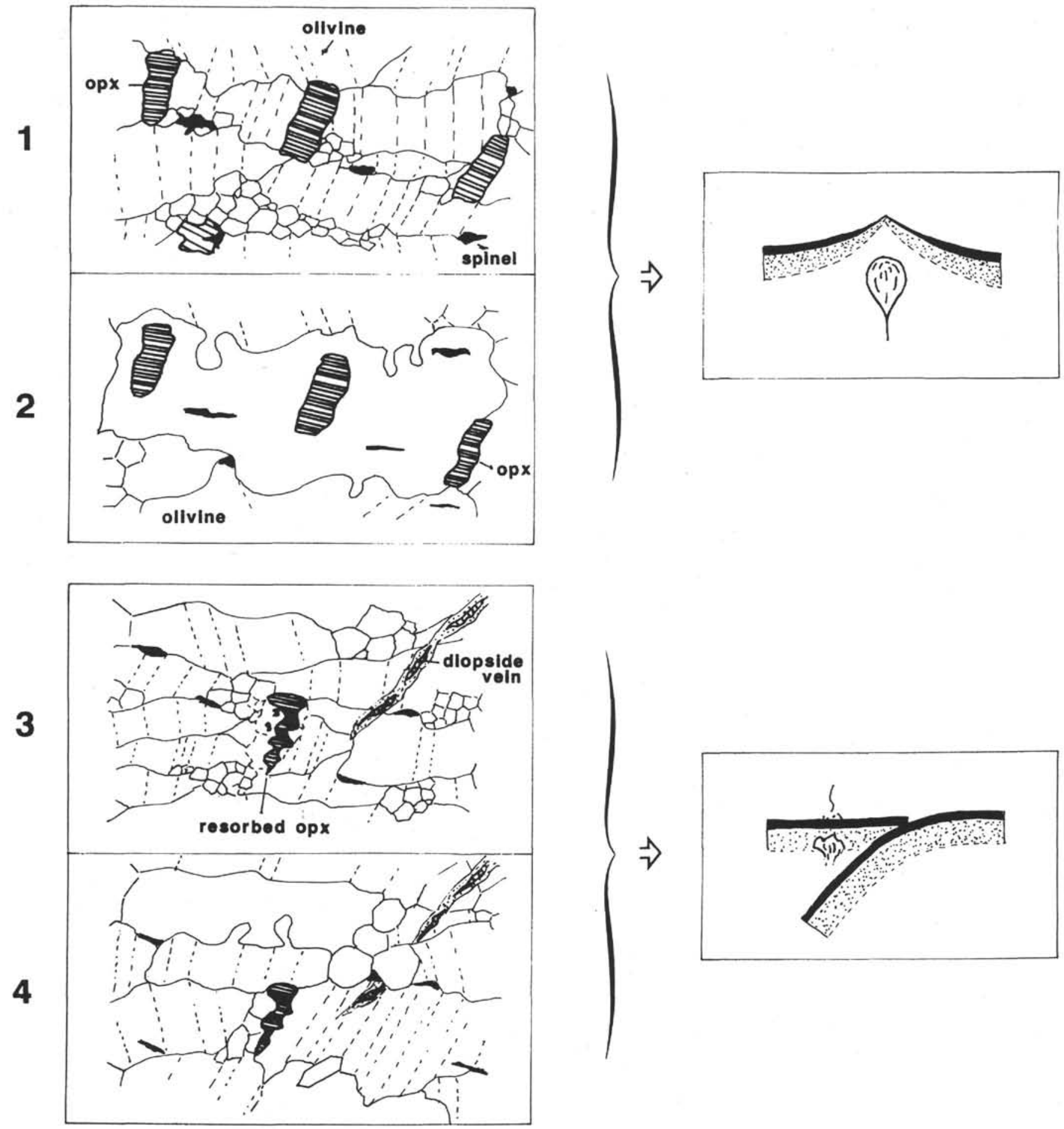

Figure 9. Sketch diagram for the high-temperature evolution of the peridotites. Event 1: the peridotite acquired a porphyroclastic texture with a foliation well marked by spinel and olivine crystals alignment. During this stretching phase, orthopyroxene grains were cut into rectangular sections by a pulling apart process. Event 2: Coarsening of olivine crystals followed the preceding deformation, producing poikilitic textures for the peridotite. Event 3: the coarse-grained peridotites underwent another stretching phase at high temperature and low stress, which yielded porphyroclastic textures for the peridotites. Undersaturated, hydrated magma/fluid percolation into the rocks produced the resorption of the orthopyroxene and subsequent crystallization of calcium-rich clinopyroxene + aluminum-rich spinel in veins cross-cutting the main foliation. Event 4: Some annealing of olivine postdates the later event. 
above. These shear zones began to develop at relatively high temperatures to permit dynamic recrystallization of olivine to occur, possibly in the presence of water allowing for early crystallization of amphibole from the orthopyroxene. It ended at low temperatures, in the stability field of chlorite and serpentine materials. These later shear zones developed at a low angle from the high-temperature foliation.

\section{Brittle Deformation (Event 6)}

The last stage of deformation recorded by the peridotites postdates their main serpentinization: it is marked by the local development of conjugate faults and by large brecciation of the rock, with infilling of fractures by serpentine materials. Such deformation probably occurred at low temperatures according to the presence of predominant chrysotile and lizardite in the veins.

\section{DISCUSSION}

According to our results, the peridotites from Sites 779 and 780 may have undergone two major episodes in relation to their primary magmatic history (events 1 to 4 ) and to their late emplacement onto the seafloor (events 5 and 6).

The high-temperature evolution (events 1 to 4 ) of the peridotite at Sites 779 and 780 does not differ significantly from the high-temperature evolution of most peridotites from ophiolites (see discussion in Nicolas, 1989). This hypothesis implies that asthenospheric conditions can be achieved in the upper mantle beneath a spreading center, either mid-oceanic ridge or island arc. The two-stage, high-temperature evolution of the peridotite that involves two successive ductile deformation events, each followed by a coarsening phase, can hardly have been achieved during a single, continuous process of upwelling mantle, however.

The large degree of depletion of the rocks suggests some remelting of the mantle in a suprasubduction zone context (Ishii et al., 1990; T. Ishii, pers. comm., 1990). We may then assume that the last high-temperature, low-stress deformation of the peridotite, the resorption of the orthopyroxene (event 3), and subsequent crystallization of clinopyroxene and the annealing of olivine (event 4) also occurred during proto-arc formation (Fig. 9, events 3 and 4). This deformation partly overprinted former deformation (event 1) and recrystallization (event 2 ) structures, however. These events may have occurred in a presubduction stage as the mantle was located in a high-temperature environment, such as a mid-oceanic ridge (Fig. 9, events 1 and 2).

The development of the ductile shear zones (event 5) remains more difficult to interpret. Our study shows that these zones can be regarded as the record of a single deformation event that began at high temperatures and ended at low ones, probably at decreasing depths. Because of the high-grade conditions for the initiation of shearing, it seems unlikely that these zones formed during late uplift of a serpentinite diapir that rose up because of gravity differences (Fryer and Fryer, 1987). We think that such a process produced the brecciation of these peridotites (event 6). The ductile shear zones may have been initiated during the late stage of upwelling of a hot mantle diapir that arrived close to the surface and that was remobilized later through serpentinization, as proposed by T. Ishii (pers. comm., 1990) or may reflect tangential movements from normal faulting. Further studies on a larger set of samples will be needed to discuss these opposite models.

\section{ACKNOWLEDGMENTS}

The authors thank the two co-chiefs of the Leg 125 cruise, Dr. P. Fryer and Dr. J. Pearce for the peridotite samples. They also thank Dr. C. A. Evans and Dr. E. M. Moores for their constructive remarks during review of the initial manuscript. This study was supported by ATP GGO.

\section{REFERENCES}

Avé Lallemant, H. G., 1977. Experimental deformation of diopside and websterite. Tectonophysics, 48:1-27.

-1985 . Subgrain rotation and dynamic recrystallization of olivine, upper mantle diapirism, and extension of the Basin-and-Range province. Tectonophysics, 119:89-117.

Berger, E. T., and Vannier, M., 1984. Les dunites en enclaves dans les basaltes des îles océaniques: approche pétrologique. Bull. Minéral., 107:649-663.

Bertrand, P., and Mercier, J.-C.C., 1985. The mutual-solubility of coexisting ortho- and clinopyroxene: toward an absolute geothermometer for natural systems. Earth Planet. Sci. Lett., 76:109-122.

Bloomer, S. H., 1983. Distribution and origin of igneous rocks from the landward slopes of the Mariana trench: implications for its structure and evolution. J. Geophys. Res., 88:7411-7428.

Bloomer, S. H., and Fisher, R. L., 1987. Petrology and geochemistry of igneous rocks from the Tonga trench: a non-accreting plate boundary. J. Petrol., 95:469-495.

Bloomer, S. H., and Hawkins, J. W., 1983. Gabbroic and ultramafic rocks from the Mariana Trench: an Island Arc ophiolite. In Hayes D. E. (Ed.), The Tectonic and Geologic Evolution of South East Asian Seas and Islands (Pt. 2): Am. Geophys. Union, Geophys. Monogr. Ser., 27:294-317.

Bonatti, E., and Michael, P. J., 1989. Mantle peridotites fron continental rifts to ocean basins to subduction zones. Earth Planet. Sci. Lett., 91:297-311.

Bowin, C. O., Nalwalk, A. J., and Hersey, J. B., 1966. Serpentinized peridotite from the North Wall of the Puerto Rico Trench. Geol. Soc. Am. Bull., $77: 257-270$.

Carter, N. L., and Avé Lallemant, H. G., 1970. High-temperature flow of dunite and peridotite. Geol. Soc. Am. Bull., 81:2181-2202.

Dick, H.J.B., 1977. Partial melting in the Josephine peridotite. I. The effect of mineral composition and its consequence for geobarometry and geothermometry. Am J. Sci., 277:801-832.

Dick, H.J.B., and Bullen, T., 1984. Chromian spinel as a petrogenetic indicator in abyssal and Alpine-type peridotites and spatially associated lavas. Contrib. Mineral. Petrol., 86:54-76.

Dietrich, V., Emmerman, R., Oberhänsli, R., and Puchelt, H., 1978. Geochemistry of basaltic and gabbroic rock from the west Mariana basin and the Mariana trench. Earth and Planet. Sci. Lett., 39:127-144.

Fryer, P., Ambos, E. L., and Hussong, D. M., 1985. Origin and emplacement of Mariana forearc seamounts. Geology, 13:774-777.

Fryer, P., and Fryer, G. J., 1987. Origins of non-volcanic seamounts in a forearc environment. In Keating, B. H., Fryer, P., Batiza, R., and Boehlert, G. W. (Eds.), Seamounts, Islands and Atolls. Am. Geophys. Union, Geophys. Monogr. Ser., 43:61-72.

Fryer, P., Haggerty, J., Tilbrook, B., Sedwick, P., Johnson, L. E., Saboda, K. L., Newsom, S. Y., Karig, D. E., Uyeda, S., and Ishii, T., 1987. Results of studies of Mariana forearcs serpentinite diapirism. Eos, 68:1534.

Fryer, P., Pearce, J., Lagabrielle, Y., et al., 1990. Manteau d'avant-arc et boninites: principaux résultats du Leg ODP 125 dans les domaines d'avantarc des Marianes et des Bonins. C. R. Acad. Sci. Sér. 2, 310:1247-1254.

Fryer, P., Pearce, J. A., Stokking, L. B., et al., 1990. Proc. ODP, Init. Repts., 125: College Station, TX (Ocean Drilling Program).

Harte, B., 1977. Rock nomenclature with particular relation to deformation and recrystallization textures in olivine-bearing xenoliths. J. Geol., 85:279-288.

Hussong, D. M., and Fryer, P., 1985. Forearc tectonics in the Northern Mariana arc. In Nasu, N. (Ed.), Formation of Active Ocean Margin: Tokyo (Terra Scientific), 273-290.

Ishii, T., 1985. Dredged samples from the Ogasawara forearc seamount or "Ogasawara paleoland"-"forearc ophiolite." In Nasu, N., Kobayashi, K., Kushiro, I., Kagami, H. (Eds.), Formation of Active Ocean Margins: Tokyo (Terra Sci. Publ.), 307-342.

Ishii, T., Robinson, P. T., Fiske, R., and Maekawa, H., 1990. Petrology of ODP Leg 125: mantle peridotites and related rocks from serpentinite diapiric seamounts in the Izu-Ogasawara Mariana forearc. GAC-MAC Joint Ann. Meeting, Vancouver. (Abstract)

Jakes, A. L., and Green, D. H., 1980. Anhydrous melting of the peridotite at 0-15 kb pressure and the genesis of tholeitic basalts. Contrib. Mineral. Petrol., 73:287-310.

Johnson, L., and Fryer, P., in press. The first evidence for MORB-like lavas from the outer Mariana forearc: geochemistry, petrography and tectonic implications. Earth Planet. Sci. Lett. 
Johnson, L., Fryer, P., Pearce, J. A., and the Shipboard Scientific Party, 1989. Mariana forearc crust sampled by serpentinite seamounts. Eos, 70:1309.

Kimball, K. L., 1990. Effects of hydrothermal alteration on the compositions of chromium spinels. Contrib. Mineral. Petrol., 105:337-346.

Kornprobst, J., and Tabit, A., 1988. Plagioclase-bearing ultramafic tectonites from the Galicia margin (Leg 103, Site 637): comparison of their origin and evolution with low-pressure ultramafic bodies in Western Europe. In Boillot, G., Winterer E. L., et al., Proc. ODP, Sci. Results, 103: College Station, TX (Ocean Drilling Program), 253-263.

Mercier, J.-C.C., 1985. Olivines and Pyroxenes, In Wenk, H. R. (Ed.), Preferred Orientation in Deformed Metals and Rocks: An Introduction to Modern Texture Analyses: New York (Academic Press), 407-430.

Mercier, J.-C.C., Anderson, D. A., and Carter, N., 1977. Stress in the lithosphere: inference from steady-state flow of rocks. Pure Appl. Geophys., 115:129-226.

Mercier, J.-C.C., and Nicolas, A., 1975. Textures and fabrics of upper mantle peridotites as illustrated by xenoliths from basalts. J. Petrol., 16:454-496.

Mysen, B., and Kushiro, I., 1977. Compositional variations of coexisting phases with degree of melting of peridotite in the upper mantle. Am. Mineral., 62:843-865.

Nicolas, A., 1986. Structure and petrology of peridotites: clues to their geodynamic environment. Rev. Geophys., 24:875-895.

, 1989. Structure of Ophiolites and Dynamics of the Oceanic Lithosphere: Dordrecht (Kluwer).

Nicolas, A., and Poirier, J.-P., 1976. Crystalline Plasticity and Solid State Flow in Metamorphic Rocks: New York (Wiley).

Orberger, B., and Alleweldt, J., in press. Platinium, palladium and $\mathrm{Ni}-\mathrm{Cu}$ sulfides bearing black serpentinite of the Acoje ophiolite block, Zambales, Philippines: mineralogical and geochemical characteristics. Can. Mineral.

Pearce, J. A., Lippard, S. J., Roberts, S., 1984. Characteristics and tectonic significance of supra-subduction zone ophiolites. In Kokelaar, B. P., and Howells, M. F. (Eds.), Marginal Basin Geology, Geol. Soc. Spec. Publ. London, 16:74-94.
Quatrevaux, F., Girardeau, J., and Ceulener, G., 1991. Magma percolation related modal, textural and chemical heterogeneities in peridotites from the Magsad diapir, Oman. EUG Meeting Abstract, Terra Cognita, 415.

Ross, J. V., Avé Lallemant, H. G., and Carter, N. L., 1980. Stress dependance of recrystallized grain and subgrain size of olivine. Tectonophysics, 70:39-61.

Sakai, R., Kusakabe, M., Noto, M., and Ishii, T., 1990. Origin of waters responsible for serpentinization of the Izu-Ogasara-Mariana forearc seamounts in view of hydrogen and oxygen isotope ratio. Earth Planet. Sci. Lett., 100:291-303.

Saraskin, A., Pustchin, I. K., Zlobin, S. K., and Kolesov, G. M., 1983. Two ophiolite sequences from the basement of the northern Tonga arc. Ofioliti, 8:411-430.

Shcherbakov, S. A., and Savel'Yeva, G. N., 1984. Structures of ultramafic rocks of the Marianas Trench and Owen Fracture zone. Geotectonics, 18:265-267.

Shipboard Scientific Party, 1990a. Site 779. In Fryer, P., Pearce, J. A., Stokking, L. B., et al., 1990. Proc. ODP, Init. Repts., 125: College Station, TX (Ocean Drilling Program), 115-145.

1990b. Site 780. In Fryer, P., Pearce, J. A., Stokking, L. B., et al., 1990. Proc. ODP, Init. Repts., 125: College Station, TX (Ocean Drilling Program), 147-178.

Date of initial receipt: 30 November 1990

Date of acceptance: 29 July 1991

Ms 125B-178 